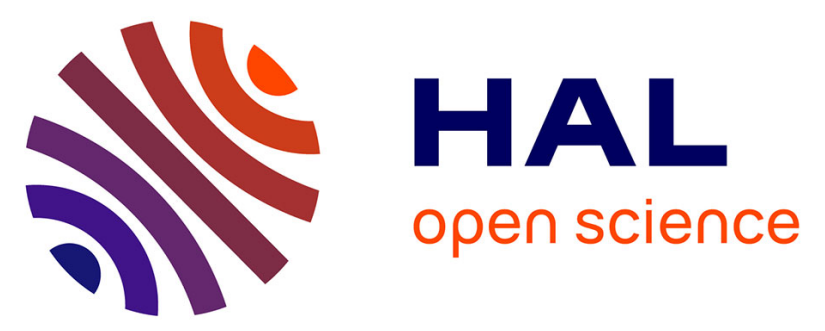

\title{
MeMoVolc consensual document: a review of cross-disciplinary approaches to characterizing small explosive magmatic eruptions
}

\author{
Lucia Gurioli, D. Andronico, Patrick Bachèlery, Hélène Balcone-Boissard, \\ Jean Battaglia, G. Boudon, Alain Burgisser, M. Burton, Katharine Cashman, \\ Sarah B. Cichy, et al.
}

\section{To cite this version:}

Lucia Gurioli, D. Andronico, Patrick Bachèlery, Hélène Balcone-Boissard, Jean Battaglia, et al.. MeMoVolc consensual document: a review of cross-disciplinary approaches to characterizing small explosive magmatic eruptions. Bulletin of Volcanology, 2015, 77, pp.49. 10.1007/s00445-015-0935-x . hal-01170133

\section{HAL Id: hal-01170133 \\ https://hal.uca.fr/hal-01170133}

Submitted on 17 Nov 2021

HAL is a multi-disciplinary open access archive for the deposit and dissemination of scientific research documents, whether they are published or not. The documents may come from teaching and research institutions in France or abroad, or from public or private research centers.
L'archive ouverte pluridisciplinaire HAL, est destinée au dépôt et à la diffusion de documents scientifiques de niveau recherche, publiés ou non, émanant des établissements d'enseignement et de recherche français ou étrangers, des laboratoires publics ou privés.

\section{(ㄷ)(1) $\$$}

Distributed under a Creative Commons Attribution - NonCommerciall 4.0 International 
1 MeMoVolc consensual document: a review of cross-disciplinary approaches to characterizing small explosive magmatic eruptions

3

L. Gurioli ${ }^{1}$, D. Andronico ${ }^{2}$, P. Bachelery ${ }^{1}$, H. Balcone-Boissard ${ }^{3}$, J. Battaglia ${ }^{1}$, G. Boudon $^{4}$, A. Burgisser ${ }^{5}$, S.B. M.R. Burton ${ }^{6}$, K. Cashman ${ }^{7}$, S. Cichy ${ }^{1}$, R. Cioni ${ }^{8}$, A. Di Muro ${ }^{9}$, L. Dominguez ${ }^{10}$, C. D’Oriano ${ }^{6}$, T. Druitt ${ }^{1}$, A.J.L Harris ${ }^{1}$, M. Hort ${ }^{11}$, K. Kelfoun ${ }^{1}$, J.C. Komorowski ${ }^{4}$, U. Kueppers ${ }^{12}$, J.L. Le Pennec ${ }^{1}$, T. Menand ${ }^{1}$, R.

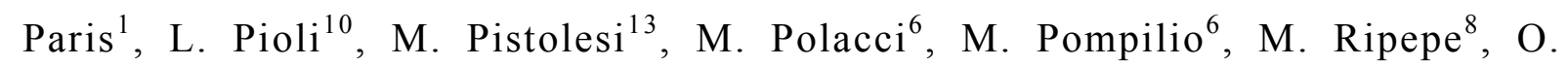
Roche $^{1}$, E. Rose-Koga ${ }^{1}$, A. Rust ${ }^{7}$, F. Schiavi ${ }^{1}$, L. Sharff ${ }^{11}$, R. Sulpizio ${ }^{14}$, J. Taddeucci $^{15}$, T. Thordarson ${ }^{16}$

1 Laboratoire Magmas et Volcans, Université Blaise Pascal - CNRS - IRD, OPGC, 5 rue Kessler, 63038 Clermont Ferrand, France

2 INGV, Osservatorio Etneo, Sezione di Catania, 95125 Catania, Italy

3 Sorbonne Universités, UPMC Univ Paris 06, UMR 7193, Institut des Sciences de la Terre Paris (iSTeP) and CNRS, F-75005 Paris, France

4 Institut de Physique du Globe (IPGP), Sorbonne Paris-Cité, Université Paris Diderot, CNRS UMR-7154, 1 rue Jussieu, 75238 Paris Cedex 05, France

\section{ISTerre Université de Savoie CNRS, 73376 Le Bourget du lac, France}

6 INGV, Sezione di Pisa, 56126 Pisa, Italy

7 School of Earth Sciences, University of Bristol, United Kingdom

8 Dipartimento di Scienze della Terra, Università degli Studi di Firenze, 50121 Florence, Italy

9 Institut de Physique du Globe (IPGP), Sorbonne Paris-Cité, CNRS UMR-7154, Université Paris Diderot, Observatoire Volcanologique du Piton de la Fournaise (OVPF), Bourg Murat, France

10 Département de Minéralogie, Université de Genève, Switzerland

11 Klimacampus, CEN, University of Hamburg, Germany

12 Ludwig-Maximilians-Universitaet (LMU), Munich, Germany

13 Dipartimento Scienze della Terra, Università degli Studi di Pisa, Italy

14 Dipartimento di Scienze della Terra e Geo-Ambientali, Università degli Studi di Bari, Italy

15 INGV, Sezione di Roma, 00143 Roma, Italy

16 Institute of Earth Sciences (IES), University of Iceland, Reykjavík, Iceland

Abstract A workshop entitled "Tracking and understanding volcanic emissions through cross-disciplinary integration: A textural working group." was held at the Universite Blaise Pascal (Clermont-Ferrand, France) on the 6-7 November 2012. This workshop was supported by the European Science Foundation (ESF). The main objective of the workshop was to 
establish an initial advisory group to begin to define measurements, methods, formats and standards to be applied in the integration of geophysical, physical and textural data collected during volcanic eruptions. This would homogenize procedures to be applied and integrated during both past and ongoing events. The workshop comprised a total of 35 scientists from six countries (France, Italy, Great Britain, Germany, Switzerland and Iceland). The four main aims were to discuss and define:

- Standards, precision and measurement protocols for textural analysis

- Identification of textural, field deposit, chemistry and geophysical parameters that can best be measured and combined

- The best delivery formats so that data can be shared between, and easily used by different groups;

- Multi-disciplinary sampling and measurement routines currently used, and measurement standards applied, by each community

The group agreed that community-wide, cross-disciplinary integration, centered on defining those measurements and formats that can be best combined, is an attainable and key global focus. Consequently, we prepared this paper to present our initial conclusions and recommendations, along with a review of the current state of the art in this field that supported our discussions.

\section{Introduction}

A major goal of modern volcanology is to relate conditions of magma ascent to the resulting eruption style using information preserved in volcanic deposits. Because it is impossible to directly observe magma ascent, vesiculation and fragmentation, one way to obtain quantitative information on magma-ascent dynamics is through textural quantification of the sampled particles. Textural quantification involves full description of the vesicle and crystal properties of erupted products (e.g., Sparks 1978; Sparks and Brazier 1982; Whitham and Sparks 1986; Houghton and Wilson 1989; Marsh 1988, 1998; Cashman and Marsh 1988, Toramaru 1989, 1990; Cashman and Mangan 1994; Higgins 2000; 2006; Blower et al. 2002; Burgisser and Gardner 2005; Shea et al. 2010a; Rust and Cashman 2011; Baker et al. 2012 and references therein). Magma viscosity, ascent rate, vesiculation processes, fragmentation style and explosion dynamics all imprint characteristic and measurable properties on the textures of volcanic particles, as shown by theoretical and experimental studies (e.g., Rust and 
Cashman 2011; Gonnerman and Houghton 2012; Degruyter et al. 2012; Nguyen et al. 2013 and references therein). The main assumption is that most of the pyroclast properties are acquired during ascent in the conduit, with few changes occurring after fragmentation or in the atmosphere, if the pyroclasts are lapilli size or smaller (e.g., Houghton and Wilson 1989; Nguyen et al. 2013). Specifically, the textural parameters of the pyroclastic components can yield insights into the dynamics of explosive eruptions, as reviewed in Table 1.

However, the physical characteristics of individual pyroclasts must not be considered in isolation from detailed studies of (i) the deposits from which they were collected, (ii) their chemical properties, (iii) geophysical signatures of the related explosive event, or (iv) petrological and/or analogue experiments. Indeed, attempts to understand eruption dynamics have been increasingly coupled to traditional fieldwork and geophysical measurements made synchronously with sample collection. In 2004, a special issue of the Journal of Volcanology and Geothermal Research (Volume 137) focused on multidisciplinary approaches, proposing "simultaneous collection of multiple geophysical data sets, such as seismic, infrasonic, thermal and deformation data, as well as sampling of ejecta and detailed mapping". The argument was that "complete constraint of a volcanic system is not possible using one data set, so that an integrated multiparametric approach involving simultaneous collection of multiple geophysical and petrological data sets will increase our ability to reach tightly constrained and confident conclusions regarding the mechanics and dynamics of volcanic systems and eruptions" (Harris et al. 2004). Since 2004, numerous studies have borne these predictions out, combining textural data with:

i. Field deposits (e.g., Polacci et al. 2006a; Rust and Cashman 2007; 2011; Mattsson 2010);

ii. Petrological data (e.g., Larsen 2008; Shea et al. 2009; 2010b; Burgisser et al. 2010; Bai et al. 2011);

iii. Chemical analyses (e.g., Piochi et al. 2005, 2008; Shimano and Nakada 2006; Noguchi et al. 2006; Costantini et al. 2010; Schipper et al. 2010a; b; c; 2011; 2012; 2013; Balcone-Boissard et al. 2010, 2011, 2012; Shea et al. 2012; 2014)

iv. Geophysical measurements (e.g., Burton et al. 2007; Gurioli et al. 2008, 2013; 2014; Polacci et al. 2009b; Andronico et al. 2008; 2009a; 2009b; 2013a, 2013b; Miwa et al. 2009; Miwa and Toramaru 2013; Colò et al. 2010; Landi et al. 2011; Pistolesi et al. 2011; Leduc et al. 2015)

Together, these studies have delivered complete pictures of explosive eruptions and their dynamics (Fig. 1). 
Despite this progress, we remain far from establishing the best protocols for sampling pyroclasts and for correlating and comparing the many parameters that can be measured using individual clasts and field deposits. Only a few papers address some of these issues (e.g., Bonadonna et al 2013; Engwell et al. 2013; Klawon et al. 2014). In addition, no study has yet attempted to correlate all derivable textural parameters with the full range of multidisciplinary data available. To partially resolve these issues, a working group funded by the European Science Foundation, through the MeMoVolc program (http://www.memovolc.fr/), was set up. The group was composed of experts actively working on integration of textural, deposit and geophysical data, equally balanced between four theme areas: (i) particle-texture studies, (ii) deposit analysis, (iii) chemistry and (iv) geophysics. The priorities of the meeting were discussion and definition of:

The core communal issues to be explored were agreed on:

1. What are the best sampling and measurement strategies for the quantification of pyroclast textural features, and what are their precision and uncertainty?

2. What are the best sampling and measurement strategies for pyroclastic deposits to allow textural characterization of their particles?

3. How can we link chemistry and particle-texture properties?

4. How can we link geophysical data and the particle-texture quantification?

5. What is the best multi-disciplinary strategy for combining output from each field in a meaningful way?

The paper reviews these topics in the light of a workshop consensus. Because of the time constraints and the complexity of the arguments, the paper focuses only on the study of explosive subaerial magmatic eruptions that generate sustained columns or fountains, and the associated fallout deposits (Fig. 1). Further workshop or working groups should be organized 
to synthesise and integrate all work in progress, and already completed, in the areas of phreatic, phreatomagmatic and submarine explosions, as well as pyroclastic density current and lava flow deposits (Table 1). .

The final objective of this paper is to ensure that data collected in the field and laboratory can be shared effectively and ingested in a multi-disciplinary sense into experiments, modeling and monitoring. In the longer term, the objective is to publish and update standards, as well as to propose, support and organize field meetings to test integrated collection methodologies. The ultimate aim is to increase the number of open-access data-bases of standard and community-accepted quality, thereby increasing resources available for crossdisciplinary correlations.

\section{Sampling of pyroclasts and quantification of their textural features}

\section{(i) Representative samples}

Pyroclasts reflect degassing of the parent magma, from the conduit to the plume. Part of the textural signature is assumed to reflect the fragmentation (or explosion) zone. Consequently, texture can be used as an indicator of magma properties (composition, porosity, connectivity, permeability, vesicle and crystal content, size, shape and distribution) at that time (Table 1). This assumption has two requirements:

i. The textural signature that was quenched immediately at the fragmentation level can be distinguished from the textural effects of post-fragmentation processes, including microlite formation and bubble nucleation, expansion, collapse, coalescence and Ostwald ripening that will change clast vesicularity or vesicle size and shapes once the pyroclast has been formed (e.g., Thomas et al. 1994; Cashman et al. 1994; Herd and Pinkerton 1997; Larsen and Gardner 2000; Gurioli et al. 2008; Costantini et al. 2010; Stovall et al. 2011, 2012). The time window for post-fragmentation changes depends on magma composition, viscosity and fragmentation depth.

ii. Because clast density is also a function of clast size (Houghton and Wilson 1989), only clasts of similar sizes must be used in order to avoid non-uniform grain-size effects on textural parameters.

We thus recommend choosing samples that are representative of the studied explosion, or unit, in terms of: 
i. Timing: This requires sampling of narrow stratigraphic intervals (Houghton and Wilson 1989) in which juvenile clasts of similar dimensions can be assumed to represent those parts of the magma fragmented at a particular time (n.b. conduit processes can change over short timescales);

ii. Distribution: This requires selection of more than one outcrop for each event;

iii. Degree of fragmentation: This requires selection of a sampling methods that is appropriate for the the full range of grain sizes in the deposit;

iv. Componentry: If the juvenile fraction is heterogeneous, then sampling should be done based on preliminary componentry analysis of the clasts analyzed (e.g., Wright et al. 2011, Eychenne et al 2015)

In previous studies, only clast sizes of 16-32 mm, i.e. coarse lapilli (White and Houghton 2006) have been considered for textural purposes. Such clasts were considered to be large enough to be easily sampled and studied, while being fully representative of the density variation of the majority of erupted pyroclasts and unaffected by significant postfragmentation phenomena (Houghton and Wilson 1989). These requirements are not always met. In basaltic magma, post-fragmentation effects can be a complication even for these sizes (e.g., Cashman et al. 1994; Szramek et al. 2006; Costantini et al. 2010; Gurioli et al. 2008; Pioli et al. 2014; Pistolesi et al. 2008; 2011; Stovall et al. 2011; 2012). In these cases, the challenge is to identify, quantify and remove post-fragmentation effects in order to isolate textures preserved across the fragmentation zone. For example, the original shapes of vesicles may be reconstructed by de-coalescencing large vesicles using the presence of broken, or partially retracted, glassy septa.

However, if we study an ash-dominated or a bomb-dominated event, particle-texture analyses must be performed on the fine or coarse juvenile fragments, respectively. Ash size particles $(<2 \mathrm{~mm})$ have been investigated recently in terms of vesicle and crystal size distributions (Taddeucci et al. 2002, 2004; Cioni et al. 2008; D’Oriano et al. 2011a, b; Miwa et al. 2009; 2013; Miwa and Toramaro 2013; Proussevitch et al. 2011; Genareau et al. 2012; 2013; Colucci et al. 2013, Schipper et al. 2013), and an extensive work has been done in the last 40 years in characterizing ash morphology and deposit componentry (Table 1). For the ash fraction, post-fragmentation expansion can be excluded (e.g., Proussevitch et al. 2011; Genareau et al. 2012; 2013; Colucci et al. 2013). Consequently, analyses allow comparison between morphological and textural features of clasts sampled in proximal and distal areas. Ash particles can record most of the information related to magma ascent dynamics (e.g., decompression-driven microlite crystallization) and fragmentation (Cioni et al. 2008; 
D’Oriano et al. 2005; D’Oriano et al. 2011a, b; Proussevitch et al. 2011; Genareau et al. 2012; 2013; Colucci et al. 2013). Advantages of studying ash are that it can also be statistically more representative of the variability of the magma properties and is less affected by density-driven settling within the plume. However, ash fragments record only small-scale vesicularity. The integration of observations made on the external shapes of clasts may give information about the presence and importance of a coarser vesicularity which drives magma fragmentation (e.g., Proussevitch et al. 2011; Genareau et al. 2012; 2013; Colucci et al. 2013). However, they cannot provide complete information about the abundance and size of the full vesicle population, if the magma included bubbles larger than the ash particles. Furthermore, ash particles are not suitable for permeability studies, as they are often smaller than the bubbles forming the permeability network. However, the presence of coalesced vesicles in a preferred direction, and an abundance of ash clasts with an elongate shape, have been interpreted as an indication of the development of a permeable bubble network (D'Oriano et al. 2011a).

Bombs may provide a plethora of information regarding pre-eruptive degassing and ascent rate (e.g. Hoblitt and Harmon 1993; Wright et al. 2007), timing and degree of thermal interaction of magma with wall-rock material prior to ejection (Rosseel et al. 2006; Sottili et al. 2009; 2010), post-fragmentation changes due to bubble growth, coalescence or shape changes (e.g. Herd and Pinkerton 1997, Shin et al. 2005) and mingling between stagnant and fresh magma (Gurioli et al. 2014; Leduc et al. 2015).

\section{(ii) Bulk measurements of particle characteristics}

The fastest and most straightforward textural measurement of individual pyroclasts is density (vesicularity), which provides basic information on processes related to gas exsolution and escape (Houghton and Wilson 1989). The densities of lapilli and small bombs can be determined by comparing their weights in water and air following the Archimedes principle. Clasts can be made impermeable with silicone waterproofing spray, by immersion in cellulose acetate, or by using Parafilm ${ }^{\mathrm{TM}}$ wax. This technique is fairly rapid and yields large arrays of data with a reproducibility within $10-30 \mathrm{~kg} \mathrm{~m}^{-3}$ and accuracy within $30 \mathrm{~kg} \mathrm{~m}^{-3}$ (Barker et al. 2012). Quicker, more timely and precise, density measurements can now be performed using a commercial envelope-density measurement device (http://www.micromeritics.com/ProductShowcase/GeoPyc-1360-Envelope-Density-Analyzer.aspx). Following the same principles, a battery-powered device has been used to vacuum-seal pumice or scoria in plastic bags in the field (Kueppers et al. 2005). 
For pyroclasts characterized by fine vesiculation (with largest vesicles smaller than 2-3 $\mathrm{mm}$ ), the density can be measured with the glass-bead method (Nakamura et al. 2008) that allows the calculation of the density as well as the volume of an object of irregular size. For large bombs (from 15 to $40 \mathrm{~cm}$ in diameter), a "natural waterproofing" effect was exploited (Gurioli et al. 2013). Extensive tests showed that decimetric size bombs collected at Stromboli acquired a "natural waterproofing" from their quenched margins and thus could be weighed in water without waterproofing. This represents an easy, precise and fast strategy for large bombs.

The derived density distributions, coupled with external morphology variation, can be used as filters to select a few clasts, representative of the low, modal and high density values, from each subpopulation observed (e.g., Shea et al. 2010a). Selected clasts are then used for textural quantification.

Other bulk particle-texture measurements include vesicle connectivity, permeability (Klug and Cashman 1996; Klug et al. 2002; Formenti and Druitt 2003; Rust and Cashman 2004; and references in Table 1) and electrical conductivity (Le Pennec et al. 2001; Bernard et al. 2007; Wright et al. 2009; Wright and Cashman 2014). The connectivity measurements are mostly performed using gas-displacement helium pycnometers, and they deliver first-order information on the outgassing capacity (i.e., potential for gas loss) of the magma near fragmentation (Klug et al. 2002; Formenti and Druitt 2003; Giachetti et al. 2010; Shea et al. 2011; 2012). Permeability controls the rate at which magma outgases during decompression. Several methods exist for permeability measurements in volcanology. Rust and Cashman (2004) used a commercial permeameter to perform systematic steady-state gas-flow experiments using porous samples, and the relationship between flow rate and pressure gradient was determined. They also introduced the Forchheimer equation into volcanology, which is a modified form of Darcy's law that includes the inertial effect of gas flow, and specified the importance of this effect in volcanic degassing processes. Mueller et al. (2005) used gas-pressure decay with time after sudden decompression in a fragmentation bomb for the permeability measurements, without measuring gas-flow rate. A falling head permeameter developed by Burbié and Zinszner (1985) has also been used to measure the permeability of volcanic porous materials (Jouniaux et al. 2000; Bernard et al. 2007). Recently, a low-cost gas permeameter was developed (Takeuchi and Nakashima, 2005) and improved (Takeuchi et al., 2008), to measure permeability of natural samples and experimental products. Finally, electrical conductivity measures how well a material transports electric charge. Rocks, in general, are poor conductors, whereas ionic fluids are good conductors. Therefore a 
measurement of conduction through fluid-saturated rocks provides information about the connected pore pathway through the sample. Although the influence of pathway tortuosity and pore shape on permeability is useful for numerical simulations on gas percolation, it has been the object of only a few studies (Table 1).

\section{(iii) Comparison between 2D and 3D particle-texture measurements}

Two different methods are currently available for extracting vesicle and crystal sizes, shapes and distributions in pyroclasts. The first is by conversion of 2D data from a planar surface (such as a thin section or photograph) to $3 \mathrm{D}$ data through stereology. The second method derives 3D data directly from X-ray tomographic reconstructions and visualization of clast textures without the need of stereological conversions (Song et al. 2001; Shin et al. 2005; Polacci et al. 2006b; 2008; 2009a, b; 2010; Degruyter et al. 2010b; Gualda et al. 2010; Giachetti et al. 2011; Baker et al. 2012), using computer software especially developed for geo-textural purposes (e.g. Ketcham and Carlson 2001; Ketcham 2005; Friese et al. 2013). Other 3D methods include serial sectioning (e.g. Bryon et al. 1995), serial focusing with optical microscope (Manga 1998), serial grinding (e.g., Marschallinger 1998a, b, c; Mock and Jerram 2005), and constructing digital elevation models of individual ash grains to calculate vesicle volume (Proussevitch et al. 2011). Two-D and 3D observations have different limitations and potential, and the two methods are becoming complementary, not competitive (e.g., Giachetti et al. 2011; Baker et al. 2011).

\section{$2 D$ method}

Standard procedures for the 2D method have been recently published for vesicles (Shea et al. 2010a) and crystals (Higgins 2000; 2006). Two-D techniques can yield high-quality data and account for both vesicle and crystal sizes in the sample and can be applied to particles ranging in size from bombs (e.g., Gurioli et al. 2014, Leduc et al. 2015) to ash (Miwa et al. 2009; 2013; Miwa and Toramaru 2013). These measurements are best used when there is a broad size distribution to be measured. The main limitation of the method is that is based on the assumption of spherical shape of the textural objects, following Sahagian and Proussevitch (1998). When this conversion is simply obtained by dividing the number of vesicles per unit area by the median value of diameter of each size class (Cheng and Lemlich 1983), no shape assumption is made. However, the $3 \mathrm{D}$ conversion is more precise when a shape is defined. Empirical corrections are commonly used for crystal analyses (Higgins 2000 and 2006), but 
for vesicles, whose shapes are less uniform, they risk introducing systematic, uncontrolled errors in the data (Sahagian and Proussevitch 1998; Proussevitch et al. 2007a; 2007b).

\section{$3 D$ method}

$\mathrm{X}$-ray-computed microtomography is the only available high-resolution, non-invasive 3D technique that allows reconstruction, visualization and processing of samples. Data acquisition is generally relatively straightforward, and several scales can be examined and combined, ranging from centimeters to $<1$ micron, depending on the resolution (Giachetti et al. 2011). In addition, the so-called 'local area' tomography technique (e.g., Lak et al. 2008) enables high resolutions to be attained, even with samples larger than the field of view of the camera. However, 3D quantification of textures can also be labor intensive, depending on the size of the volume that needs to be analyzed and on the textural parameters required. The results show the internal structures of samples, highlighting how objects and apertures are linked together. This information provides an excellent suite of data for studies of vesicle size, shape and distribution, collapse, deformation, coalescence, permeability, and tortuosity, as well as for determining crystal volume, size and distribution and visualizing crystal aggregates in 3D (Polacci et al. 2009a, b; 2012; Bai et al. 2010, 2011; Degruyter et al. 2010a, b; Zandomeneghi et al. 2010; Gualda 2010a, b; Baker et al. 2012; Castro et al. 2012; Okumura et al. 2013). Vesicles with complex shapes are easily identified, while in a 2D section they might be interpreted as two or more vesicles, thus biasing vesicle size distribution (VSD) and vesicle number density $\left(\mathrm{N}_{\mathrm{v}}\right)$ (e.g. Giachetti et al. 2011). The 3D method is particularly effective for determining $\mathrm{N}_{\mathrm{v}}$ if the study is focused on a specific size range; vesicle number densities over a wide range of sizes is achieved with nested studies in which a series of scans are done at different sizes and resolutions (e.g. Giachetti et al. 2011; Pardo et al. 2014b). However, the resolution of the reconstruction is still critical. Klug et al. (2002) showed that vesicle walls may be as thin as $0.1 \mu \mathrm{m}$. To achieve this sort of spatial resolution using tomography requires very small samples. When the attained resolution is $5-15 \mu \mathrm{m}$, thin vesicle walls are not resolved.

There is currently no unique protocol for 3D measurements of different types of pyroclastic (or lava) samples; however the SYRMEP group of the Elettra Synchrotron Light Source (Trieste, Italy), together with researchers at McGill University of Montreal and INGV Pisa (M. Polacci), are developing protocols for volcanic samples of different vesicularities and crystallinities. 
Crystal size distribution (CSD) is a well-established tool for interpreting the physical processes and environmental variables that drive differentiation and crystallization in magma chambers and conduits (e.g., Marsh 1988; Cashman and Marsh 1988; Cashman 1992; Hammer et al. 1999; Cashman and McConnell 2005, Armienti 2008; also see references in Table 1). CSD, coupled with vesicle distribution data, yield deeper insights into the physical processes operating in the conduit (e.g., Gurioli et al. 2005; D’Oriano et al. 2005; Piochi et al. 2005; 2008; Noguchi et al. 2006; Giachetti et al. 2010; D’Oriano et al. 2011a; Vinkler et al. 2012). The CSD method has been well tested and widely applied (Table 1), so that it is now quite straightforward to quantify CSD (Higgins 2000; 2006; and references in Table 1).

However, we must keep in mind that crystals are commonly anisotropic, and therefore shape cannot be ignored. Most studies use the Higgins technique to account for shape. However, the Higgins method assumes that all crystals are the same shape. This is clearly not true, as small crystals are often more anisotropic than large crystals. Treating all crystals in the same way can introduce artifacts (see Castro et al. 2003). In addition, there are still resolution issues for microlites, as well as problems in both back-scattered electron (BSE) and cathode ray tube (CRT) analyses when the crystals have a density ( $Z$ number) near that of the glass. Several methods can be used to facilitate the extraction and quantification of crystals. CSDs of larger crystals (phenocrysts, antecrysts, etc.) can be measured from transmitted light microscopy images of thin sections and analyzed with digital image analysis to automate and hence speed up the quantification process (e.g., Armienti et al. 1994; Launeau et al. 1994; Lumbreras and Serrat 1996; Goodchild and Fueten 1998; Launeau and Cruden 1998; De Keyser 1999; Heilbronner 2000; Armienti and Tarquini 2002; Boorman et al. 2004). Tarquini and Favalli (2010) used a slide scanner to acquire input imagery in transmitted light from thin sections and GIS software to analyze the data.

Crystals can also be identified using a scanner and a polarizing filter placed at different angles (Pioli et al. 2014). Three pictures are then combined, and their correlation allows the individual grains to be classified by their characteristic orientation. To measure smaller crystals (microphenocrysts and microlites), a scanning electron microscope is commonly used in backscattered electron (BSE) mode (Cashman 1992; Hammer et al. 1999; Cashman and McConnell 2005; Nakamura 2006; Ishibashi and Sato 2007; Salisbury et al. 2008; Blundy and Cashman 2008; Wright et al. 2012). Development of rapid x-ray mapping techniques now allows CSD analysis of x-ray element maps, which provide information on crystal 
compositions, textures (crystal size, orientation, shape) and modes of minerals (e.g., Muir et al. 2012; Leduc et al 2015). Another new technique uses an electron backscatter diffraction detector (EBSD) attached to the SEM to obtain crystal orientations, which can provide insights into shearing, accumulation and degassing processes (Prior 1999; Prior et al. 1999; Hammer et al. 2010). Chemical mapping is now routinely and widely used (e.g., Leduc et al. 2015). In contrast, EBSD is more difficult to use and interpreting the data is harder than the chemical maps. As described in the references cited, it produces a wealth of information on various minerals, although the monocline structure of the feldspar can be problematic.

Crystal size distribution can also be obtained directly in 3D via X-ray computed microtomography. Using this approach, it is possible to obtain the total crystal volume, as well as the crystal volume of each mineral phase present: crystallinity, crystal size and crystal shape (e.g., Zandomeneghi et al. 2010; Voltolini et al. 2011). Again, resolution can be a problem. First, crystals may span a large size range, which requires imaging at several different resolutions (e.g., Pamukcu et al. 2010; 2012). Additionally, as in BSE analysis, the compositional similarity between some crystal phases, such as alkali feldspars, and silicic matrix glass can make automated analysis challenging (e.g., Baker et al. 2012). However, excellent results can be obtained by working in phase-contrast tomographic mode (Polacci et al. 2010), and applying a procedure known as phase retrieval to the reconstructed sample volumes (Arzilli et al. 2013).

\section{(v) Errors in particle-texture analyses}

Uncertainties in textural analysis are due to several factors. Any textural parameter, such as porosity or crystal size, has intrinsic measurement errors. These are linked to the apparatus used and are generally easy to quantify using standards. A good practice, when a new method is introduced, is to assess its intrinsic error with synthetic samples of well-known particles, having textural components (e.g. crystals, vesicles/voids) with known size and distribution (e.g., see review of Rust and Cashman 2004 for permeability, and Baker et al. 2011 for 3D data from X-ray microtomography). Another type of uncertainty is linked to natural variability, which is generally approached by using the concept of Representative Elementary Volume (REV, Bear 1972). Parameters measured in small, neighboring, regions within a sample have a large variability. As the analyzed regions become larger, this variability decreases until a steady value is reached at the REV size. One complication is that the REV should be significantly smaller than the sample (not guaranteed for ash, or even lapilli, 
particles), and that some parameters have an REV at the deposit scale, which means that many clasts have to be analyzed. If the sample location is such that eruptive parameters were steady during deposition, application of REV at the deposit scale allows analysis of magma at the point of fragmentation in the conduit. Taking porosity as an example, one 2D SEM image will yield one porosity measurement with a typically small $(\sim 1 \%)$ intrinsic error due to thresholding of the grayscale values that represent vesicles. Several 2D images of the same sample taken at different locations and/or different resolutions (larger than the REV) typically yield larger ( $\sim 10 \%)$ uncertainties that are caused by small-scale spatial heterogeneity. Finally, if we assume that - or if we have a - very well sorted deposit, then the density distribution of all clasts at that location indicates the variability of porosity at the conduit scale, which can be quite large (e.g., Houghton and Wilson 1998). The situation is more complex with poorly sorted deposits in which particles range from bombs through lapilli to ash.

Raw data in terms of size (area, long axis, short axis, perimeter) and orientation of crystals and vesicles yield negligible intrinsic errors, because they are computed with programs on 2D binary images with high resolution $\left(>10^{6}\right.$ pixels). In this phase, the uncertainty is due to the image clean-up process, which is generally unquantified (because it takes too long to have four people complete the task independently and then take the average for every image).

The greatest source of intrinsic error here is thresholding, which is set by the operator (Baker et al. 2011). When converting 2D data to a 3D projection, however, the error depends on the stereological model used (i.e. particle shapes have to be assumed, Cashman 1988) and is thus harder to estimate.

Most 2D textural parameters have well-established techniques and protocols to quantify intrinsic errors, including:

- VSD (Toramaru 1990; Mangan et al. 1993; Klug and Cashman 1994; 1996; Klug et al. 2002; Adams et al. 2006b; Shea et al. 2010a),

- CSD (Higgins 2006), fabric indicators (Launeau et al. 1990),

- vesicle shape (Moitra et al. 2013),

- clast shape (Marshall 1987; Capaccioni and Sarocchi 1996; Dellino and Liotino 2002; Riley et al. 2003; Ersoy et al. 2006).

However, conversion from 2D to $3 \mathrm{D}$ distributions introduces errors linked to stereological assumptions. The Cheng and Lemlich (1983) method does not involve assumptions of object shape, but it does not take into account a truncation effect (e.g. Pickering et al. 1995). Truncation is related to the sensitivity of the measurement process; smaller objects are 
increasingly difficult to detect. On the other hand, large-scale truncation occurs under several circumstances related to sample-size (volume and area) limitations. The Sahagian and Proussevitch (1998) conversion assumes spherical shapes and corrects for the cut effect (this being the effect induced by rarely cutting a spherical object through its exact center). Giachetti et al. (2011) found that $\mathrm{N}_{\mathrm{v}}$ obtained by 2D and 3D methods for the same lapilli agreed within $15 \%$, and that VSD were also very similar. They recommended the Cheng and Lemlich (1983) method for 2D vesicle analysis, as the Sahagian and Proussevitch (1998) method may generate negative values for some size classes.

In terms of parameters that we can derive from textural analyses, decompression rate is probably one of the most important to quantify due to its implications for eruption dynamics. To achieve this, microlite shape, $\mathrm{N}_{\mathrm{v}}$ and size distribution have been used in combination with experimental data for low-mass flux and effusive eruptions (Couch et al. 2003; Cashman and McConnell 2005; Szramek et al. 2006; Clarke et al. 2007; Martel 2012; Wright et al. 2012). Martel et al. (2006) consider this approach to be highly reliable, because different generations of microlites (nucleated pre-eruptively in the reservoir or syn-eruptively in the conduit) can be distinguished on the basis of chemical composition. Decompression rates deduced from $\mathrm{N}_{\mathrm{v}}$ (e.g., Toramaru 2006), however, tend to be maximum estimates, because there could be more nucleation events during ascent that add to the signature left by decompression. Maximum decompression rates associated with the final, rapid, stages of ascent could be calculated directly from the smallest bubbles formed during the final fragmentation event (Giachetti et al. 2010; Shea et al. 2011; 2012). Another developing method is to use chemical gradients of volatiles in melt inclusions in crystal embayments to infer rise rates (Ferguson et al. 2013).

However, the relationships between bubble shape, nucleation, coalescence, deformation and/or fragmentation are not well established yet.

\section{Quantification and sampling of pyroclastic deposits for the textural characterization of}

\section{their components}

(i) Preliminary field studies and sampling strategy

Field-based studies of pyroclastic deposits aim to relate both the whole-deposit characteristics (thickness and grain size) and the physical properties of the constituent particles to the eruption conditions. Particle-texture studies are time consuming, especially when they provide complete size distributions of the vesicle and crystal population. For these measurements, the 
choice of a limited number of "representative" clasts selected for the analysis is critical, particularly when using these data to model eruption processes and their variability in time and space. Obtaining such clasts requires a cautious sampling strategy with well-defined scientific goals during field work. These studies are best performed only on well-documented deposits, supported by a robust stratigraphic reconstruction and correlation, as well as an accurate compositional stratigraphic framework. When not familiar with the deposit, a preliminary survey at different locations is useful to evaluate the significance of the outcrops used for detailed analysis. Well-defined sublayers (or units) should be identified in the deposit on the basis of clear, unequivocal lithologic and sedimentologic features and cross-correlated over the whole dispersal area of the deposit. Stratigraphic data are critical for placing each studied layer within an appropriate temporal framework within the stratigraphic sequence.

Pyroclasts can be collected after the eruption, from fall deposits of old (unobserved) or recent (observed) eruptions, for which sampling is done preferably within hours to days of the event (e.g., Gurioli et al. 2008; 2013). Sampling may also take place during eruptive activity, with samples collected using sampling device placed inside the fallout field. Three simple collection methods that can be applied to active fallout, as currently used, are: (1) the hand collection method involves collecting (and quenching) bombs or lapilli as they fall out of the plume by people standing in the active fallout field (e.g., Lautze and Houghton, 2007, 2008; Gurioli et al. 2014); (2) the "clean surface" strategy, whereby plastic sheets are laid out close to the vent, or a preexisting surface is cleaned before the eruption. In both cases the pyroclasts falling in a known area are collected (e.g., Rose et al. 2008; Andronico et al. 2009a; 2013a and b; Eychenne et al. 2012; Houghton et al. 2013, Harris et al. 2013b, Schipper et al. 2013); (3) the bucket strategy, in which a large number of buckets are distributed across a discrete area of fallout for a certain period of time (e.g., Yoshimoto et al. 2005; Swanson et al. 2009; Bustillos and Mothes 2010). When possible, the aims are to collect a sufficient number of samples to estimate the magnitude of the event through the mass load per unit area; and to obtain a sufficient number of clasts for chemical and textural characterization. Other promising methods are just coming on-line, such as automatic ash sampling collectors (e.g., Bernard 2013; Shimano et al. 2013, Marchetti et al. 2013).

Definition of essential, basic physical properties of the deposit to the study

Most particle and deposit texture studies aim at characterizing magma heterogeneity and ascent dynamics, and at understanding the fragmentation process, beginning with the size, 
morphology and componentry of the particles (Table 1). Clasts selected for particle-texture analysisare usually sampled in a deposit at a single location (reference section). Lateral variability across the deposit is filtered by transport and sedimentation processes, which primarily depend on eruption intensity, along with related plume dynamics and other dynamic effects such as wind direction and velocity and rainfall. Therefore, clast properties can differ both in time (from the base to the top of a vertical sequence) and in space (from the main axis of dispersal to lateral outcrops at the edge of the fallout zone across the cloud, and from proximal to distal sites). Volcanic plumes (and clouds) are thus complex systems, the properties of which do not vary linearly with the main eruption parameters. They are also affected by external variables, such as wind direction and velocity. The external variables add additional complexity to the clast-type distribution. For this reason, the deposit should be preliminarily characterized at least in terms of stratigraphy, dispersal, thickness variation and volume before more detailed study is initiated (e.g., Fisher and Schmincke 1984; Cas and Wright 1987; Thordarson et al. 2009; Cioni et al. 2011). Estimation of plume height, eruption duration, volume and magma eruption rate can then also be derived for past eruptions from such analyses (e.g., Carey and Sparks 1986; Pyle 1989; Fierstein and Nathenson 1992; Sparks et al. 1997; Bonadonna et al. 1998; Freundt and Rosi 1998; Bonadonna and Costa 2012; Fagents et al. 2013).

\section{(iii) Selecting the outcrop}

There are three basic criteria for sample outcrop selection. First: minimize the effect of wind dispersal. Outcrops located along the main dispersal axis are preferred to lateral exposures, unless the effect of wind is the target of study. If wind direction or eruption intensity changes during different phases of the same eruption, it is more appropriate to sample each tephra layer at different 'equivalent' locations rather than to collect all samples at a single type outcrop. If sampling is restricted to a single location, the inferred dispersal pattern and distance from the main dispersal axis of each layer should be noted and taken into account when analyzing clast variability among different layers.

A second criterion for selecting the outcrop is that clear textural variations among the juvenile clasts, in terms of color, general morphology, vesicularity, vesicle shape, and crystallinity should be evaluated in the preliminary field survey, so that any lateral and vertical variability within the deposit is already defined following field reconnaissance. This 
ensures that, when clast types are chosen in the laboratory, the main textural types are easily identified and separated.

The third criterion for outcrop selection, if one of the goals of the study is quantification of the proportion of distinct textural clast types, is to remember that sedimentation from the volcanic plume is affected by clast density, shape and size (Bonadonna et al. 1998; Pfeiffer et al. 2005; Barsotti et al. 2008; Eychenne et al. 2013, and references therein). This is especially relevant when a single explosion produces a juvenile population with a wide range of textural and other physical features: their relative proportions within the deposit can vary laterally in the deposit as well as with distance from the vent. Thus, at any single site, the sample is not necessarily representative of the abundance within the eruption mixture. This is especially true in the case of small plumes and mid-intensity eruptions (e.g., Rose et al. 2008; Cioni et al. 2008; 2011; D’Oriano et al. 2011a; Andronico et al. 2013a and references therein). While the textural features of the different clast types can be studied at a single outcrop, the relative proportions between clast types need to be determined across the whole deposit by integrating componentry data on samples collected at outcrops at differing azimuths and distances from the source.

\section{(iv) Sampling}

After identification of the outcrops where the deposit shows the best and most complete exposure, a suitable approach is random collection of a statistically relevant number of clasts from a single layer. Several techniques can be used, ranging from sieving in the field to find the dominant clast size (for coarse clasts), or sampling the bulk deposit for later clast selection in the laboratory (for small clasts). In the case of fine-grained deposits, it can be useful to apply sampling techniques that preserve structural and textural characteristics of the whole deposit. Samples can be retrieved using tubes or boxes manually pressed into the deposits, or carfully carved out and surround-wrapped deposit blocks. In situ and/or laboratory impregnation techniques of deposits exist for a broad range of grain sizes and compositions (Bouma 1969), some of which are applicable to fragile or loose volcanic deposits (e.g. Fiske et al 2009). The applicability of such techniques to fine-to-medium grained volcanic deposits should be tested, since they would allow both 2D (e.g., X-ray radiography and thin section analysis) and 3D analysis (X-ray tomography and anisotropy of magnetic susceptibility) to be applied to deposits, rather than single pyroclasts; these, techniques are frequently used for hard rocks (e.g., Lanza and Meloni 2006). 
The number of samples should be defined depending on the purpose of the study.

578 Fixing the number of samples per stratigraphic layer based on the layer characteristics (e.g., extent of zoning/fluctuations in grain-size, componentry, etc.) for characterizing eruption dynamics, or focusing on the layer thickness for conduit dynamic characterizations, are two examples of such pre-selection decisions. Before selecting clasts, basic grain-size studies

582

583

584

585

586

587

588

589

590

591

592

593

594

595

596

597

598

599

600

601

602

603

604

605

606

607

608

609 (when the bulk deposit is collected) on each sampled layer (median and sorting of grain-size distribution) and componentry analysis should be carried out to ensure effective sub-sampling for textural studies. Following White and Houghton (2006) componentry analysis is the subdivision of the sample into three broad components: juvenile, non-juvenile particles and composite clasts. The juvenile components are vesicular or dense fragments, as well as crystals, that represent the primary magma involved in the eruption; non-juvenile material includes accessory and accidental fragments, as well as crystals, that predate the eruption from which they are deposited. Finally, the composite clasts are mechanical mixtures of juvenile and non-juvenile (and/or recycled juvenile) clasts. More-detailed componentry can subdivide the juvenile and non-juvenile materials into subpopulations that have important dynamic meanings (e.g., Eychenne et al. 2015).

Finally, after choosing the size intervals of the clasts for physical and textural measurements (i.e., bulk and solid density, vesicularity, microtextures, permeability), it is useful to compare the grain-size distribution of each interval with the total grain-size distribution of the sampled layers, especially when the grain-size distribution is highly variable within the sampled stratigraphy. This strategy allows checking of sample representativeness. For example, sampling may be from (i) bimodal or complex multimodal distributions, or (ii) anomalous, poorly sorted deposits. In the second case, sampling should avoid features that can be indicative of contamination from other sources, such as ballistic components, elutriated ash from pyroclastic density currents or from reworking (e.g., Fierstein et al. 1997, Eychenne et al. 2012). It is useful, whenever possible, to show variance, or invariance, of the textural features by comparing data collected in the selected size class with textural data for different size classes. This should, at least, be carried out for a few selected samples. 
Geochemical and petrological analysis of pyroclastic products can constrain the initial conditions in the shallow crustal holding chamber through to the surface via the conduit system (Fig. 1). In transit through this system, the textural features are imprinted on the pyroclasts quenched upon eruption. The geochemical and petrologic analysis can help:

- Define pre-eruptive P-T storage conditions from mineral-melt equilibria or disequilibria (e.g., Rutherford et al. 1985; Scaillet and Evans 1999; Pichavant et al. 2002; Blundy and Cashman 2008; Schipper et al. 2010b);

- Assess initial viscosity, temperature, melt composition and volatile budget, including input of gases from deeper sources (e.g., Wallace 2001; Blundy and Cashman 2008; Métrich et al. 2010);

- Define the evolution of volatile contents (specifically $\mathrm{CI}, \mathrm{F}, \mathrm{S}, \mathrm{H}_{2} \mathrm{O}, \mathrm{CO}_{2}$ ) using electron probe, ion probe (SIMS), Raman and FTIR in melt inclusions and host minerals, while combining results with vesiculation studies and gas release measurements (e.g., Wallace 2005; Métrich and Wallace 2008, Schipper et al. 2010c). In such a way we can determine whether the magma was saturated, over-saturated or under-saturated at a certain depth, and how these conditions affect vesiculation in the conduit (e.g., Anderson 1991; Hurwitz and Navon 1994; Dixon 1997; Roggensack et al. 1997; Schipper et al. 2012);

- Measure residual volatiles in glasses and bulk-rock samples to reveal how degassed the magma is (Newman et al. 1988; Villemant and Boudon 1998; Shea et al. 2014);

- Provide variable diffusion of stable elements $\left({ }^{6} \mathrm{Li},{ }^{7} \mathrm{Li}, \mathrm{H} / \mathrm{D},{ }^{10} \mathrm{~B},{ }^{11} \mathrm{~B}\right)$ or radiogenic isotopes $\left({ }^{210} \mathrm{~Pb}^{226} \mathrm{Ra}\right)$, which are used as tracers for melt degassing and interaction with hydrothermal fluids (e.g., Berlo et al. 2004; Kent et al. 2007; Humphreys et al. 2008b; Schiavi et al. 2010; Berlo and Turner 2010; Vlastélic et al. 2011);

- Measure mineral diffusion profiles and derive pre-eruptive residence times, ascent rates and cooling rates (e.g., Kahl et al. 2011);

- Provide crystal shapes, zoning schemes, and dissolution stages, while determining which magmatic process and physical parameters control crystal shape/zoning (e.g., Hammer and Rutherford 2002; Rutherford and Devine 2003; Blundy et al. 2006; Costa et al. 2008; Streck 2008);

In addition, laboratory petrological investigations can provide: 
660

- Experimental observations on phase equilibria (mineral-melt-vapor), crystallization paths and liquid line of descent (e.g., Hammer and Rutherford 2002; Couch et al. 2003; Blundy et al. 2006; Hammer 2008);

- Calibration of decompression rates. While this has been carried out for rhyolitic systems (e.g., Mourtada-Bonnefoi and Laporte 2002, 2004; Mangan and Sisson 2005; Gardner 2007; Cichy et al. 2011; Cluzel et al. 2008) and phonolitic systems (e.g., Larsen 2008; Shea et al. 2010b), there are ongoing studies on basaltic systems (Bai et al. 2008; Lesne et al. 2011; Pichavant et al. 2013);

- Diffusion coefficients of relevant chemical elements, including volatiles, to improve kinetic modeling (Dohmen et al. 2007; Chakraborty 2008);

- Relationships between crystal morphologies, cooling rates and degree of undercooling (e.g., growth of crystals with hopper and swallow tail shapes experiencing rapid latestage crystallization; Faure et al. 2003, 2007);

- Surface flux of volatiles (i.e. what leaves the system; see reviews by Fischer 2008; Pyle and Mather 2009) compared with melt inclusion data (i.e. what is in the system initially; e.g., Le Voyer et al. 2010; Rose-Koga et al. 2012; Schiavi et al. 2012).

2) Where geochemistry can help textural study

Measurements of volatile contents in quenched, phenocryst-hosted melt inclusions provide estimates of initial (shallow crustal) values (e.g., Kent 2008). These are minimum estimates, because $\mathrm{H}_{2} \mathrm{O}$ can leak from melt inclusions during ascent by intracrystalline diffusion as the far-field environment of the crystal evolves (Chen et al. 2011, 2013). Melt inclusion volatile contents can be inverted to equivalent saturation pressures using multi-species (e.g., $\mathrm{H}_{2} \mathrm{O}-$ $\mathrm{CO}_{2} ; \mathrm{H}_{2} \mathrm{O}-\mathrm{Cl}$ ) solubility laws (using, for example, VOLATILCALC, Newman and Lowenstern 2002; MELTS, Ghiorso and Sack 1995; Asimow and Ghiorso 1998). These, in turn, can be used to calculate total pressures (and hence depth) by assuming volatile saturation, or minimum pressures if the sample is under-saturated in volatiles. Progressive closure of melt inclusion networks in growing phenocrysts can result in zone-dependent melt inclusion volatile contents that record the evolution of pressure conditions as magmas migrate from depth (Blundy and Cashman 2008, and references therein). Combining major element and volatile compositions of the melt with phenocryst contents allows calculation of initial magma physical properties (viscosity, density, surface tension, and others). Derivations of 
such parameters are necessary for modeling magma ascent, vesiculation and groundmass crystallization.

Pre-ascent storage conditions can also be inferred from phase-equilibria studies of natural compositions. Comparison of natural and experimental phase abundances and compositions, combined with constraints of volatile content (from melt inclusions) and temperature (from e.g., Fe-Ti oxides) allows estimation of total pressure if the degree of volatile saturation is established through use of mixed-volatile experiments (Pichavant et al. 2007; Cadoux et al. 2014).

Residual volatile content (e.g., $\mathrm{H}_{2} \mathrm{O}, \mathrm{CO}_{2}, \mathrm{SO}_{2}, \mathrm{Cl}, \mathrm{F}$ ) measured in the glass or directly from gases emitted at the vent can be correlated with textures (e.g., Piochi et al. 2005; 2008; Schipper et al. 2010a; Balcone-Boissard et al. 2011, 2012; Shea et al. 2012, 2014; Burton et al. 2007; Polacci et al. 2009b; Miwa and Toramaru 2013). The residual volatile contents can also be compared with pre-eruptive volatile contents obtained from melt inclusion to evaluate both the extent and efficiency of syn-eruptive degassing (e.g., Shimano and Nakada 2006; Noguchi et al. 2006, Métrich et al. 2001; 2010). Residual water content or Cl content (when $\mathrm{Cl}$ partitions into a $\mathrm{H}_{2} \mathrm{O}$ vapor phase, so that it can thus be used as an indicator of degassing processes; Balcone-Boissard et al. 2010) is typically plotted against $V_{g} / V_{l}$, where $V_{g}$ is the volume of vesicles corrected for phenocrysts and $\mathrm{V}_{1}$ is the volume of melt and microlites (Villemant and Boudon 1998, Balcone-Boissard et al. 2011, 2012). An important issue is to assess the extent of post-eruption hydration. Recently, thermal gravimetric studies have proved to be quite effective in allowing this correction based on oxygen or hydrogen isotopic compositions (e.g., Giachetti and Gonnerman 2013; Shea et al. 2014). Studies of hydrogen isotopes, correlated with SEM glass textures, permit distinction of magmatic water from meteoric water generated by re-hydratation (Kyser and O'Neil 1984). Hydration can also be assessed from the ratio of water species (molecular $\mathrm{H}_{2} \mathrm{O}$ vs. $\mathrm{OH}$ ) in residual glass, as determined by FTIR data or Raman analyses (Hammer et al. 1999; Le Losq et al. 2012).

Ascent and decompression in the conduit can result in chemical changes that can be quantified by a range of microbeam analytical techniques (e.g., EPMA, LA-ICPMS, FTIR, $\mu-$ Raman). As the pressure drops, $\mathrm{H}_{2} \mathrm{O}$ will migrate out of melt inclusions and crystals (Le Voyer et al 2010; Hamada et al 2010), and light elements (Li, B) will try to re-establish equilibrium between crystals, host melt and any vapor or brine phase present (Berlo et al. 2004). At the same time, $\mathrm{H}_{2} \mathrm{O}$ and $\mathrm{CO}_{2}$ migrating out of melt inclusions will become apparent as re-entrant tubes at the edges of crystals (Liu et al. 2007; Humphreys et al. 2008a). Each of these processes will establish diffusive gradients frozen into the pyroclast that can be 
measured and modelled using experimentally determined kinetic laws to infer decompression rates during ascent (e.g. Gonnermann and Manga 2013). These decompression rates can then be compared with values derived from other approaches, including those based on analyses of microlite sizes and shapes, vesicle number densities, and hornblende-breakdown reactions (e.g., Martel 2012; Cluzel et al. 2008; Giachetti et al 2010; Shea et al. 2011).

\section{3) Contentious points}

Care needs to be taken when converting decompression rate to magma ascent rate, and especially when comparing decompression rates obtained using different methods. Pressure gradients in conduits are highly nonlinear due to the strong effect of dissolved $\mathrm{H}_{2} \mathrm{O}$ on magma viscosity, particularly at low $\mathrm{H}_{2} \mathrm{O}$ contents (Gonnermann and Manga 2013). Moreover, different processes will likely record different decompression rates, according to the time available for the process to take place. For example, microlite growth is relatively slow, so that microlite size and shape distributions are likely to record an average decompression rate during ascent (Martel 2012). Bubble nucleation and growth, on the other hand, can occur very rapidly, so that $\mathrm{N}_{\mathrm{v}}$ may record just the peak decompression rate immediately beneath the fragmentation zone (Cluzel et al. 2008; Giachetti et al 2010). Comparison of rate calculations from different methods therefore requires caution. However, integration of decompression rates as obtained from different textural and chemical characterizations, when combined with mass eruption rate estimation from deposit analysis or direct observations, can provide quantitative insights into the processes involved in magma ascent from the deep source to the surface.

Another outstanding issue is the role of dense clasts. That is, did they originate (i) from magma quenched at depth prior vesiculation, (ii) by vesicle collapse in an originally vesicular clast, (iii) from volatile-poor magma or from reciclying? It is important to provide a correct interpretation, because the three conclusions relate to very different mechanisms. In several eruptions it has been found that the densest clasts were depleted in water through syneruptive bubble collapse and coalescence (Rust and Cashman 2007; Piochi et al. 2008, Shea et al. 2014). In Plinian eruptions at Vesuvius (Pompeii and Avellino), the densest clasts have been interpreted as magma that lost water during transition from closed-to open-system degassing (Balcone-Boissard et al. 2011; 2012). Water depletion can also result from syn-eruptive processes, such as clast recycling at magmatic temperature (Gurioli et al. 2014) and intrinsic magmatic redox conditions, as shown by the experiments of D'Oriano et al. (2012). No study 
has yet have demonstrated that dense clasts retain all of their original gas and were quenched at great pressure.

Another key question is whether the measured compositions (including volatile content) of bulk rock, glass, or minerals represent equilibrium or disequilibrium processes, and if equilibrium or disequilibrium conditions pertain to local subsystems or to the whole magmatic body under investigation (see for example Pichavant et al. 2007). Chemical species with different diffusivities, for example, record equilibrium or non-equilibrium conditions in the same sample (e.g. De Campos et al. 2008; Schipper et al. 2012). Equilibrium kinetics is also composition-dependent, because it is dictated in part by melt viscosity which is itself related to viscosity. This issue will generally affect silicic to intermediate magmas more than basaltic magmas. However, we note that even for basaltic systems crystal-fluid-bubble magma mixtures can achieve apparent viscosities that range over six orders of magnitude, up to $10^{6}$ Pa s (e.g., Gurioli et al. 2014), depending on the degree of cooling, degassing and crystallization. Such rheological variation even within a single composition, and its effect on eruption mechanisms, deserves increased attention.

\section{How to link the geophysical data with pyroclast textural quantification}

A wide array of remote sensing and geophysical approaches can be used to parameterize an explosive event, both within and outside the conduit (Fig. 1). Geophysical signals are generated by fluid and gas flow in the magma-filled part of the conduit and during fragmentation. Magma-gas ascent dynamics and conduit conditions extracted from geophysical data for this part of the system are particularly difficult to validate because the system cannot be directly observed. They are thus effectively "invisible" to direct observation. Measurements outside the conduit can be made of the emitted mixture of gas and particles as it (i) exits the vent, (ii) ascends above the vent as a plume, and then (iii) drifts away from the vent as the cloud. Models and dynamic parameters extracted for geophysical and remote sensing data outside the conduit are a little easier to validate because they can be directly observed.

The invisible part of the system is the realm of studies using seismic, pressure (infrasonic), and deformation data. All three data sets have long been shown capable of detecting the geophysical signature of explosive events spanning weakly explosive Hawaiianto-Strombolian through Plinian events. Seismic data sets are available, for example, for gaspistoning events, puffing, fountains, and strombolian eruptions at mafic systems (e.g., 
Goldstein and Chouet 1994; Ripepe et al. 1996; Sciotto et al. 2011; Ripepe and Braun 1994), as well as for events that generate somewhat larger plumes during silicic eruptions, as at Santiaguito, Soufriere Hills, and Redoubt. Associated pressure impulses (typically recorded by infrasound and barometers) have long been recorded for such energetic events, famous examples including the pressure response to the 1883 eruption of Krakatoa and the 1967 caldera-forming eruption of Fernandina (Simkin and Howard 1970). Magma-gas ascent has also been shown to generate rapid, but recordable, deformation signals detected by tiltmeters (Aoyama and Oshima 2008; Genco and Ripepe 2010; Iguchi et al. 2008; Zobin et al 2007).

Velocities, masses and size distributions of particles leaving the vent have typically been measured by visible and thermal video (e.g., Chouet et al. 1974; Ripepe et al. 1993; Harris et al. 2012; Delle Donne and Ripepe 2012; Taddeucci et al. 2012; Bombrun et al. 2014; Gaudin et al., 2014a, b) and Doppler radar (e.g., Dubosclard et al 1999; Hort and Seyfried 1998; Vöge et al 2005; Gouhier and Donnadieu 2008; 2011; Gerst et al 2013). Infrasonic array methods are also available to locate the emission in x,y space (Ripepe and Marchetti 2002). Plume front velocities, density and entrainment rates have also been successfully tracked using visible and thermal cameras, as well as radiometers, for a few stronger, ash-rich, buoyant plumes at Stromboli, Santiaguito and Eyjafjallajökull (Patrick 2007; Sahetapy-Engel and Harris 2009; Bjornsson et al. 2013; Valade et al. 2014); See Chapter 9 of Harris (2013) for review.

Satellite remote sensing has long been used to track and measure properties of the eruption cloud as it drifts and disperses. These data are available for all cloud sizes, from those associated with small Strombolian and fountaining events (e.g., Heiken and Pitts 1975; Dehn et al. 2000; 2002) to sub-Plinian and Plinian events (e.g., Holasek and Self 1995; Koyaguchi and Tokuno 1993; Holasek et al. 1996). Cloud dispersion dynamics are especially well revealed by geostationary satellite data with nominal imaging of one image every 15 minutes and higher. Basic cloud properties that can be measured by satellite data include cloud dimensions, drift velocity and height (e.g., Robock and Matson 1982; Denniss et al. 1998; Aloisi et al. 2002; Zakšek et al 2013). Prata (1989) and Wen and Rose (1994) introduced a method to potentially extract particle size distribution and mass from "split window" $(10-12 \mu \mathrm{m})$ thermal data. While specially modified ground-based thermal cameras were adapted to extract ash particle size and plume mass (Prata and Bernardo 2009), newly available technology such as LiDAR and PLUDIX were shown of value in detecting, tracking and measuring fine particles in the Eyjafjallajökull cloud (e.g., Bonadonna et al. 2011). Disdrometers and ash collectors, however, currently show greater potential for measuring 
particle size and terminal velocity (Marchetti et al. 2013; Shimano et al. 2013) than PLUDIX, which was designed more for meteorological applications (Caracciolo et al. 2006; Prodi et al. 2011).

For the gas content of the cloud, satellite-based sensors such as TOMS, AIRS, OMI, MODIS, GOME and IASI have been used to obtain the $\mathrm{SO}_{2}$ content in the far field, once the gas cloud has decoupled from the ash cloud (e.g., Krueger et al. 1990; Carn et al. 2003; 2005; Watson et al. 2004; Yang et al. 2007; Thomas et al. 2011; Rix et al. 2012; Walker et al. 2012). Ground-based sensors, such as COSPEC, FLYSPEC and DOAS (e.g., Caltabiano et al. 1994; Horton et al. 2005; Oppenheimer et al. 2011), have been used to measure $\mathrm{SO}_{2}$ fluxes relatively close to the source; see Williams-Jones et al (2008) for full review. These approaches have been recently supplemented by $\mathrm{SO}_{2}$ camera systems, which allow $2 \mathrm{D}$ images of $\mathrm{SO}_{2}$ concentrations to be collected at $\sim 1 \mathrm{~Hz}$ rates (Mori and Burton 2006). Such studies have, though, tended to focus on passive degassing and gas-puffing systems, because the presence of ash interferes with UV-light transmission on which the technique relies, making measurements problematic. Recently, $\mathrm{SO}_{2}$ cameras have been used to measure the gas masses and fluxes involved in discrete explosive events (Mori and Burton 2009; Holland et al 2011; Barnie et al. 2014).

However, none of these remote sensing techniques directly collects or makes contact with the magma or particles they measure. Thus the need exists for quality ground-truth data to validate particle velocities and sizes extracted from what is, basically, an electronic response, as well as to test the assumptions and models used to convert received "power" to a more meaningful and useful parameter (such as mass). At the same time, any single data set can be inverted to support a conduit or plume dynamic model; but results need to fall within constraints provided by ground-truth data. In this case, ground truth is provided by analyses of the magma and particles themselves to extract parameters such as magma temperature, chemistry, density, crystallinity and vesicle content, as well as vesicle shape and size and particle density, size, shape and roughness. Magma ascent, explosion-source and fragmentation models based on geophysical data likewise need to be consistent with independent measurements made for physical volcanology for the same processes if they are to be valid. We explore below these needs, mostly focusing on weakly explosive, basaltic cases, the usual targets because they provide a reliable and easy-to-measure source for testing new technology, methods and algorithms for ground-based geophysical enquiry.

\section{The basic need: Realistic assumptions and validation}


The basic response of a remote sensing instrument is a voltage which, through calibration, can be converted at higher level physical value, such as spectral radiant intensity or power. The conversion of this value to higher level and more volcanologically useful parameters (such as particle-size distribution, mass flux or plume density) requires an increasingly complex system of assumption stacking. Thus, to adequately reduce geophysical data, a number of input parameters are required and many assumptions need to be made, all of which can be provided by the physical volcanological community. Data sets from this community, especially if provided simultaneously with geophysical data collection during an active event, or provided as a library typical of that event, can also be used to "ground truth" or check the precision and reality of the geophysically applied input or generated output.

Seismic signals that accompany explosions are primarily short period (SP; high frequency $>1 \mathrm{~Hz}$ ) signals which are typically termed "explosion quakes". These usually have high amplitudes and mostly include frequencies up to a few hertz, with a possible higher frequency acoustic phase (McNutt 1986, Mori et al. 1989, Braun and Ripepe, 1993). Below these frequencies, short period (SP) signals are often hidden by very-long period (VLP) components with much lower amplitudes (Neuberg et al. 1994; Kaneshima et al. 1996). In-spite of an enormous amount of work, it remains unclear as to how we can explain the VLP seismic component, which itself is only one part of the seismic signal. It also remains unclear as to whether, and/or how, SP and VLP components are related to the magnitude and intensity of an explosion, although attempts have been made using tremor (Brodsky et al. 1999; Nishimura and McNutt 2008; Prejean and Brodsky 2011). Clearly, better coupling with the physical volcanology community could help narrow down much uncertainty and allow progress towards better models to untangle the seismic signal associated with discrete explosive events.

Delay times in the arrival of seismic, infrasonic and thermal signals have been commonly used to assess the depth at which various physical processes occur in explosive basaltic systems (e.g., Ripepe and Braun 1994; Ripepe et al. 2001; 2002; Harris and Ripepe 2007). However, the sound speed in the conduit needs to be assumed if, for example, the thermalinfrasound delay is to be used to obtain the fragmentation depth. This will vary strongly with conditions in the empty portion of the conduit, including mixture density, gas-to-particle ratio, and temperature of the mixture through which the sound is propagating. Thus we need to know these variables if we are to provide a realistic sound speed value and hence infer a plausible depth. We thus need to constrain two fundamental parameters to strengthen geophysical modelling of the shallow explosion mechanism and depth. First, the magma crystal and bubble content (as well as size, shape and distribution), plus fluid chemistry and 
temperature, are needed to define magma rheology properties and bubble ascent dynamics. Second, the exact proportions and character of the mixture of gas and particles that ascends the final section of the conduit to exit the vent and feed the emission must be known.

Velocities, mass fluxes and particle size distributions (PSDs) for lapilli through bomb-size particles have been derived from high spatial and temporal resolution video data obtained using both near-infrared and thermal cameras (Chouet et al. 1974; Ripepe et al. 1993; Harris et al. 2012; Delle Donne and Ripepe 2012; Bombrun et al. 2014).

Generally, these studies have focused on Stromboli. For such camera data, the lower limit of a particle size that can be extracted is limited by pixel size. This is typically about one centimeter in dimension, depending on the detector's instantaneous field of view and distance to the target (Harris 2013). A pixel-mixture model can be applied to obtain the size of a subpixel particle, but it needs to assume a temperature for the particle and then uses the pixelintegrated temperature to solve for the pixel portion occupied by that particle (Harris et al. 2013a). Symmetry then needs to be assumed to convert from particle area to particle volume, and a density needs to be assumed to derive particle mass (Bombrun et al. 2014). For ash-rich plumes, methods have been applied to extract total plume mass and air entrainment properties from ascent dynamics of buoyant thermals (Wilson and Self 1980; Patrick 2007; Valade et al. 2014). However, all methods need particle shape, particle density, plume density and/or size distribution data to: (i) determine whether the input assumptions are valid; and (ii) ground truth the remote-sensing-data-derived size and mass data (Harris et al. 2013a and b). The advantage is, if a validated method can be developed, particle size distribution, mass and mass flux data for the plume leaving the vent can potentially be provided multiple times per second using camera data (e.g., Taddeucci et al. 2012; Bombrun et al. 2014).

Deducing the erupted mass from Doppler radar data requires the assumption of a particle size distribution for the eruption. Because this distribution is unknown, an average particle size can be constrained from the Doppler radar measurement, typically using the eruption velocities themselves deduced from either terminal fall velocities (Hort et al 2003) or by discriminating between lapilli (larger than a few millimeters or $1 \mathrm{~cm}$, depending on the radar wavelength) and fine ash particles $(<1 \mathrm{~mm})$ using their temporal velocity evolution (Valade and Donnadieu 2011). Both methods can be used to obtain an estimate for the erupted mass of ballistics. We thus need to know whether the constrained average particle size can be used for mass calculation, whether the assumption is a good approximation, and what the difference between the derived value and true value is. 
The radar is able to measure particles of all sizes, provided enough particles are available to return a signal. The relationship between particle size and number of particles required for a signal that exceeds the noise level is not linear, however. It also depends on the radar wavelength and the distance between the radar and target. The smaller the radar wavelength, and/or the smaller the distance between the radar and target, the smaller the number of fine particles needed for a return signal. For particles $<1 \mathrm{~mm}$, halving the particle size increases the number of required particles by a factor of 64 . Doubling the size of particles to $>1 \mathrm{~cm}$ means that only $1 / 4$ of the number of particles is needed to return the same signal amplitude. In addition, radar can measure at points (gates) across the entire plume thickness. Currently, radar's best role is to provide radial velocity measurements, with well-stated limits as to the particle size to which these data relate, through the entire plume thickness.

\section{Questions, points and issues}

The main question from the geophysical community to the textural community is: "What does the magma look like at the point of fragmentation?" Geophysical analysts need to know everything possible about the fragments physically in order to reduce and model the data correctly. To help with this, we concluded that:

- Measurements of basic geophysical parameters (such as seismic energy, acoustic energy, energy partitioning, spectral radiance, and radar power) are the most straightforward to consider for correlations with parameters derived from physical volcanology.

- Multi-disciplinary correlations lead to improved understanding of explosion dynamics, and only a complete set of measurements can enable a complete and well-constrained understanding of the system (e.g., Gurioli et al. 2013; 2014; Leduc et al 2015).

- A wealth of textural and geophysical data exist for Strombolian events, and some data for larger events. They have been used to define the characteristic geophysical and textural signatures that allow distinguishing each event type (e.g. Patrick et al. 2007; Leduc et al 2015). Focus on such relatively low energy events is appropriate, because they are frequent and approachable (Harris and Ripepe 2007).

- There is an unfortunate, but understandable, lack of multi-disciplinary data for larger (Vulcanian-to-Plinian) events; because they are rare. With multi-disciplinary approaches becoming more routine, this situation is improving.

Thermal and $\mathrm{SO}_{2}$ sensor arrays are becoming increasingly common components of permanent monitoring arrays at many persistently active sites (Harris 2013). However, such technology 
will probably never be installed on every potentially active volcano, all of which give seismic and pressure signals detectable by distant stations. From a practical point of view, it is more realistic to push forward with operational correlations between seismic-infrasonic metrics and deposit and particle textural deliverables to understand the ongoing progression of global volcanic events. In doing so, we must remember that many geophysical signals tend to be time-averages (e.g., tremor amplitude). We need to consider, however, geophysical measurements that describe single, discrete explosions if we are to reasonably compare the data with textural variations between many individual emission events, or emission phases, that characterize the total eruption total energy is one prime example (e.g., Marchetti et al 2009).

We are at an exciting point in our ability to track and understand explosive volcanic emissions through true cross-disciplinary integration of deposit, geochemical, textural and geophysical data. Studies are increasingly bringing together multiple approaches in the field (e.g., Rosi et al. 2006), in the laboratory (Clarke et al. 2009), at large-scale experiments (Sonder et al. 2013) and during field deployments (Harris et al. 2013b). As a community, we appear to be converging on the correct, multi-disciplinary approach. We are at the beginning of a new age, one which links particle texture to seismology (Miwa et al. 2009; Miwa and Toramaru 2013; Gurioli et al. 2014; Leduc et al. 2015) and infrasound (Colò et al. 2010, Landi et al. 2011); as well as petrology to geophysics (Saunders et al. 2012; Martí et al. 2013). Continuation of this trajectory can be aided by further support for pan-disciplinary workshops, meetings and working groups, the objectives of which are to totally understand the system and to constrain measurements with the least uncertainty.

\section{Questions, needs and recommendations}

Tables 2-4 summarize the main results from the previous discussions. Table 2 is the summary of major conclusions to date from cross-disciplinary approaches. Table 3 suggests improvements to methods to facilitate cross-disciplinary approaches. Finally, Table 4 groups outstanding questions that might be addressed if the recommended methods are used.

The list of key issues and questions defined allows us to distil the following communitywide points and initiatives as priorities:

1. We need to define, and adhere to, standard sampling, data collection, experimental and methodological procedures to allow full integration of the four disciplines; 
2. In doing this, we need to understand each other's needs, and then follow each other's well-recognized sampling etiquette in order to work together as a truly integrated team;

3. We should aim to collate all data and measurements that can be provided by each discipline at some central host site and evaluate whether we need more from each field;

4. Quantification and statement of the precision of the measurements must always be made, and a set of standards must be produced to allow data quality control has to be followed;

5. The community needs to explore and discuss the best means to improve the quality of the measurements and the amount of data available;

6. Guidelines should be agreed on regarding essential key parameters that need to be extracted, versus those that are less important. Common standards need to be established that allow these key parameters to be shared by all groups;

7. Central to this is creation of an open access data bank to support essential geophysical, deposit, textural and geochemical data integration and sharing. This means creation of a repository of data grouped by eruptive style and/or geographic location into which members can make deposits and withdrawals;

8. All of this should ideally be integrated into a GIS platform to allow for easy crosscorrelation and comparison of different types of parameters.

\section{DynVolc: an integrated database}

Inspired by this effort, a database - DynVolc (Dynamics of Volcanoes) - is now operative at http://wwwobs.univ-bpclermont.fr/SO/televolc/dynvolc/index.php. This database is part of an observation system within the services provided by Observatoire de Physique du Globe de Clermont-Ferrand (OPGC). It is an attempt to provide an integrated and accessible library for all multi-disciplinary data sets for explosive eruptive events. This database is an integrated collection of data from physical and geophysical observations of dynamic volcanic processes.

DynVolc database spans the full range of explosive and effusive activity. Its intent is to provide a library of standards for eruptive styles, for each of which the data base provides:

- field data (i.e., results of field mapping, outcrop and sample descriptions)

- key deposit features (thickness, areal dispersion, sedimentary structure, grain size)

- clast characterization (componentry, morphology, density, porosity, permeability) 
- clast texture (connectivity, vesicle and crystal size and size distributions)

- chemical analyses of samples (bulk and glass chemistry

- associated geophysical measurements (e.g., fragmentation depth, ejection and ascent velocity, fragment and gas mass, seismic and acoustic energies)

Integration of these data allows improved, better constrained, insights into the dynamics driving each eruptive style. It also allows improved definition of the rheological and degassing conditions associated with each activity style. At the same time it provides a library of key physical parameters that need to be assumed by geophysical data reduction methods, as well as during model-based enquiry.

Central to this initiative will be the transformation of this database into a communal databank, involving a web-based GIS platform to allow huge amounts of cross-correlationand comparison between parameters relating to different processes and cross-correlation of different datasets obtained for the same eruption. It is intended as an open database into which anyone can input, and withdraw, citable cross-disciplinary information for scientific analysis. At the same time, through this library, we can provide cross-community time series, baseline and monitoring data for the full range volcanic activity.

\section{Acknowledgements}

L Gurioli thanks the MeMoVolc, European Science Foundation grant (ref. n. 4253). G Valentine D Swanson and the editor, J White are thanked for their constructive reviews. This research was financed by the French Government Laboratory of Excellence initiative no ANR-10-LABX-0006, the Région Auvergne, and the European Regional Development Fund. This is Laboratory of Excellence ClerVolc contribution number XXX

\section{References}

Adams NK, Houghton BF, Hildreth W (2006a) Abrupt transitions during sustained explosive eruptions: examples from the 1912 eruption of Novarupta, Alaska. Bull Volcanol 69:189-206

Adams NK, Houghton BF, Fagents S, Hildreth W (2006b) The transition from explosive to effusive eruptive regime: The example of the 1912 Novarupta eruption, Alaska. GSA Bulletin 118 (5/6):620-634. doi: 10.1130/B25768.1 

Tephra stratigraphy and eruptive volume of the May, 2008, Chaiten eruption, Chile. Bull Volcanol 73 (5):613-630

1048

Alfano F, Bonadonna C, Gurioli L (2012) Insights on rhyolitic eruption dynamic from textural analysis: the example of the May Chaitén eruption (Chile). Bull Volcanol 74(9):2095-2108. doi $10.1007 / \mathrm{s} 00445-012-0648-3$

Aloisi M, D’Agostino M, Dean KG, Mostaccio A and Neri G (2002). Satellite analysis and PUFF simulation of the eruptive cloud generated by the Mount Etna paroxysm of 22 July 1998. J Geophys Res 107(B12): 2373. doi: 10.1029/2001JB000630

1056

Anderson AT (1991) Hourglass inclusions: theory and application to the Bishop Rhyolitic Tuff. Am Min 76:530-547

1059

Andronico D, Corsaro RA, Cristaldi A, Polacci M (2008) Characterizing high energy 1061 explosive eruptions at Stromboli volcano using multidisciplinary data: an example from the 9 January 2005 explosion. J Volcanol Geotherm Res 176:541-550. doi:10.1016/j.jvolgeores.2008.05.011

Andronico D, Scollo S, Cristaldi A, Ferrari F (2009a), Monitoring ash emission episodes at Mt. Etna: The 16 November 2006 case study. J Volcanol Geotherm Res 180 (2-4):123-134. doi:10.1016/j. jvolgeores.2008.10.019

1068

Andronico D, Cristaldi A, Del Carlo P, Taddeucci J (2009b) Shifting styles of basaltic explosive activity during the 2002-03 eruption of Mt Etna, Italy. J Volcanol Geotherm Res 180(2-4):110-122. doi:10.1016/j.jvolgeores.2008.07.026

Andronico D, Lo Castro MD, Sciotto M, Spina L (2013a) The 2010 ash emissions at the summit craters of Mt Etna: Relationship with seismo-acoustic signals. J Geophys Res 118:511075 70. doi:10.1029/2012JB009895 
Andronico D, Taddeucci J, Cristaldi A, Miraglia L; Scarlato P, Gaeta M (2013b) The 15 March 2007 paroxysm of Stromboli: video-image analysis, and textural and compositional features of the erupted deposit. Bull Volcanol 75:733. doi 10.1007/s00445-013-0733-2

Aoyama H and Oshima H (2008) Tilt change recorded by broadband seismometer prior to small phreatic explosion of Meakan-dake volcano, Hokkaido, Japan. Geophys Res Lett 35. doi:10.1029/2007GL032988

Armienti P (2008) Decryption of igneous textures: crystal size distribution tools. Rev Mineral Geochem 69:623-649

Armienti P, Tarquini S (2002) Power law olivine crystal size distributions in lithospheric mantle xenoliths. Lithos 65:273-285

Armienti P, Pareschi M, Innocenti F, Pompilio M (1994) Effects of magma storage and ascent on the kinetics of crystal growth. The case of the 1991-92 Mt.Etna eruption. Contrib Mineral Petr 115:402-414

Arzilli F, Voltolini M, Mancini L, Cicconi MR, Giuli G, Carroll MR (2013) Spherulites in trachytic melts. Mineral Mag 77(5):622

Asimow PD, Ghiorso MS (1998) Algorithmic modifications extending MELTS to calculate subsolidus phase relations. Am Mineral 83:1127-1131

Bai L, Baker DR, Rivers M (2008) Experimental study of bubble growth in Stromboli basalt melts at 1 atmosphere. Earth Planet Sci Lett 267:533-547. doi:10.1016/j.eps1.2007.11.063

Bai L, Baker DR, Hill RJ (2010) Permeability of vesicular Stromboli basaltic glass: Lattice Boltzmann simulations and laboratory measurements. J Geophys Res 115:B07201. doi:10.1029/2009JB007047

Bai L, Baker DR, Polacci M, Hill RJ (2011) In-situ degassing study on crystal-bearing Stromboli basaltic magmas: implications for Stromboli explosions. Geophys Res Lett 38:L17309. doi.org/10.1029/2011GL048540 
1112 Baker DR, Polacci M, LaRue A (2011) A study on the reproducibility of counting vesicles in volcanic rocks. Geosphere 7:70-78

1114

Baker DR, Mancini L, Polacci M, Higgins MD, GAR. Gualda, R.J. Hill, M.L. Rivers (2012) An introduction to the application of X-ray microtomography to the three-dimensional study of igneous rocks. Lithos 148:262-276

Balcone-Boissard H, Villemant B, Boudon G (2010) Behavior of halogens during the degassing of felsic magma. Geochem Geophys Geosyst 11(9):477-485. doi:10.10029/2010GC003028

Balcone-Boissard H, Boudon G, Villemant B (2011) Textural and geochemical constraints on eruptive style of the 79AD eruption at Vesuvius. Bull Volcanol. doi 10.1007/s00445-0100409-0

Balcone-Boissard H, Boudon G, Ucciani G, Villemant B, Cioni R, Civetta L, Orsi G (2012). Magma degassing and eruption dynamics of the Avellino Pumice Plinian eruption of SommaVesuvius (Italy). Comparison with the Pompeii eruption. Earth Planet Sci Lett 331-332:257268. doi: 10.1016/j.eps1.2012.03.011

Barsotti S, Neri A, Scire JS (2008). The VOL-CALPUFF model for atmospheric ash dispersal: 1. Approach and physical formulation. J Geophys Res 113:B03208. doi:10.1029/2006JB004623

Barker SJ, Rotella MD, Wilson CJN, Wright IC, Wysoczanski RJ (2012) Contrasting pyroclast density spectra from subaerial and submarine silicic eruptions in the Kermadec arc: implications for eruption processes and dredge sampling Bull Volcanol 74:1425-1443. doi:10.1007/s00445-012-0604-2

Barnie T, Bombrun M, Burton MR, Harris A and Sawyer G (2014) Quantification of gas and solid emissions during Strombolian explosions using simultaneous sulphur dioxide and infrared camera observations.

Volcanol Geotherm Res 
Bear J (1972) Dynamics of fluids in porous media. Dover, New York

Belien IB, Cashman KV, Rempel AW (2010), Gas accumulation in particle-rich suspensions and implications for bubble populations in crystal-rich magma. Earth Planet Sci Lett 297(12):133-140. doi:10.1016/j.epsl.2010.06.014

Berlo K, Turner S (2010) ${ }^{210} \mathrm{~Pb}^{226} \mathrm{Ra}$ disequilibria in volcanic rocks. Earth Planet Sci Lett (Frontiers) 296:155-164

Berlo K, Blundy J, Turner S, Cashman K, Hawkesworth C, Black S (2004) Geochemical precursors to volcanic activity at Mount St. Helens, USA. Science 306:1167-1169

Bernard B (2013) Home-made ashmeter: a low-cost, high-efficiency solution to improve tephra field-data collection for contemporary explosive eruptions. J Appl Volcanol 2:1

Bernard ML, Zamora M, Geraud Y, Boudon G (2007) Transport properties of pyroclastic rocks from Montagne Pele'e volcano (Martinique, Lesser Antilles). J Geophys Res 112:B05205.doi.org/10.1029/2006JB004385

Bindeman IN (2003) Crystal sizes in evolving silicic magma chambers. Geology 31:367-370

Bjornsson H, Magnusson S, Arason P and Petersen GN (2013) Velocities in the plume of the 2010 Eyjafjallajökull eruption. J Geophys Res Atmos 118:698-711 doi:10.1002/jgrd.50876

Blower JD (2001a) Factors controlling permeability-porosity relationships in magma. Bull

Blower JD (2001b) A three-dimensional network model of permeability in vesicular material. from bubble size distributions. Geophys Res Lett 28(2):347-350 
Blower JD, Keating JP, Mader HM, Phillips JC (2002) The evolution of bubble size

1179 distributions in volcanic eruptions. J Volcanol Geother Res 120:1-23. http://dx.doi.org/10.1016/S0377-0273(02)00404-3

Blundy J, Cashman KV (2008) Petrologic reconstruction of magmatic system variables and processes. Rev Mineral Geochem 69:179-239.

Blundy J, Cashman K, Humphreys M (2006) Magma heating by decompression-driven crystallization beneath andesite volcanoes. Nature 443:76-80

Bombrun M, Barra V, Harris A (2014) Algorithm for particle detection and parameterization in high-frame-rate thermal video. J Appl Remote Sens 8(1):083549. doi:10.1117/1.JRS.8.083549

Bonadonna C, Costa A (2012) Estimating the volume of tephra deposits: A new simple strategy. Geology 40 (5):415-418. doi:10.1130/G32769.1

Bonadonna C, Ernst GGJ, Sparks RSJ (1998) Thickness variations and volume estimates of tephra fall deposits: the importance of particle Reynolds number. J Volcanol Geotherm Res $81: 173-187$

Bonadonna C, Genco R, Gouhier M, Pistolesi M, Cioni R, Alfano F, Hoskuldsson A, Ripepe M (2011) Tephra sedimentation during the 2010 Eyjafjallajökull eruption (Iceland) from deposit, radar, and satellite observations. J Geophys Res 116(B12202). doi:10.1029/2011JB008462

Boorman S, Boudreau AE, Kruger FJ (2004) The lower zone-critical zone transition of the Bushveld complex: a quantitative textural study. J Petrol 45:1209-1235

Bouma AH (1969) Methods for the study of sedimentary structures. Jhon Wiley and Sons, 
Bouvet de Maisonneuve C, Bachmann O, Burgisser A (2009) Characterization of juvenile pyroclasts from the Kos Plateau Tuff (Aegean Arc): insights into the eruptive dynamics of a large rhyolitic eruption. Bull Volcanol 71:643-658

1213

Braun T, Ripepe M (1993) Interaction of seismic and air waves as recorded at Stromboli volcano. Geophys Res Lett 20(1):65-68

Brodsky E, Kanamori H, Sturtevant B (1999) A seismically constrained mass discharge rate for the initiation of the May 18, 1980 Mount St. Helens eruption. J Geophys Res 104:29,38729,400

Bryon DN, Atherton MP, Hunter RH (1995) The interpretation of granitic textures from serial thin sectioning, image analysis and three-dimensional reconstruction. Miner Magaz 59:203211

Burbié T, Zinszner B (1985) Hydraulic and acoustic properties as a function of porosity in Fontainebleau sandstone. J Geophys Res 90:11524-11532

Burgisser A, Gardner JE (2005) Experimental constraints on degassing and permeability in volcanic conduit flow. Bull Volcanol 67:42-56

Burgisser A, Poussineau S, Arbaret L, Druitt TH, Giachetti T, Bourdier JL (2010) Preexplosive conduit conditions of the 1997 Vulcanian explosions at Soufrière Hills Volcano (Montserrat): I. pressure and vesicularity distributions. J Volcanol Geotherm Res 194 (13):27-41. doi:10.1016/j.jvolgeores.2010.01.008

Burton MR, Mader HM, Polacci M (2007) The role of gas percolation in quiescent degassing of persistently active volcanoes. Earth Planet Sci Lett 264:46-60. doi:10.1016/j.eps1.2007.08.028 ash collection for quantifying accumulated volumes, Cities On Volcanoes abstract volume, Tenerife. Canary Island, Spain, May 31 - June 42010, 2.7-O-07 
Büttner R, Dellino P, Zimanowski B (1999) Identifying magma-water interaction from the surface features of ash particles. Nature 401:688-690

Büttner R, Dellino P, La Volpe L, Lorenz V, Zimanowsky B (2002) Thermohydraulic explosions in phreatomagmatic eruptions as evidenced by the comparison between pyroclasts and products from Molten Fuel Interaction experiments. J Geophys Res 107 (B11):2277. doi:10.1029/2001JB000511.

Cadoux A, Scaillet B, Druitt TH, Deloule E (2014). Magma storage conditions of large Plinian eruptions of SantoriniVolcano (Greece). J Petrology 55(6):1129-1171. doi:10.1093/petrology/egu021

Caltabiano T, Roman R and Budetta G (1994) SO2 flux measurements at Mount Etna (Sicily). J Geophys Res 99:12 809 - 12819

Capaccioni B, Sarocchi D (1996) Computer-assisted image analysis on clast shape fabric from the Orvieto-Bagnoregio ignimbrite (Vulsini District, central Italy): implications on the emplacement mechanisms. J Volcanol Geotherm Res 70(1-2):75-90. doi: 10.1016/03770273(95)00049-6

Caracciolo C, Prodia F, Uijlenhoetc R (2006) Comparison between Pludix and impact/optical disdrometers during rainfall measurement campaigns. Atmos Res 82(1-2):137-163

Carey RJ, Houghton BF, Thordarson T (2009) Abrupt shifts between wet and dry phases of the 1875 eruption of Askja Volcano: microscopic evidence for macroscopic dynamics. J Volcanol Geotherm Res 184:256-270

Carey RJ, Manga M, Degruyter W, Swanson D, Houghton B, Orr T, Patrick M (2012) Externally triggered renewed bubble nucleation in basaltic magma: The 12 October 2008 eruption at Halema'uma'u Overlook vent, Kīlauea, Hawai'i, USA. J Geophys Res 117:B11202. doi:10.1029/2012JB009496

Carey RJ, Manga M, Degruyter W, Gonnermann H, Swanson D, Houghton B, Orr T, Patrick M (2013) Convection in a volcanic conduit recorded by bubbles. Geology 41(4):395-398 
1279 Carey S, Sparks RSJ (1986) Quantitative models of the fallout and dispersal of tephra from volcanic eruption columns. Bull Volcanol 48:109-125. doi:10.1007/BF01046546

Carey S, Maria A, Sigurdsson H (2000) Use of fractal analysis for discrimination of particles from primary and reworked jökulhlaup deposits in SE Iceland. J Volcanol Geotherm Res $104: 65-80$

Carn SA, Krueger AJ, Bluth GJS, Schaefer SJ, Krotkov NA, Watson IM, Datta S (2003)

Volcanic eruption detection by the Total Ozone Mapping Spectrometer (TOMS) instruments: a 22-year record of sulfur dioxide and ash emissions. In: Volcanic Degassing (eds. C Oppenheimer, DM Pyle and J Barclay), Geological Society, London, Special Publications, 213, pp.177-202.

Carn SA, Strow LL, de Souza-Machado S, Edmonds Y, Hannon S (2005) Quantifying tropospheric volcanic emissions with AIRS: the 2002 eruption of Mt. Etna (Italy). Geophys Res Lett 32(2):L02301. doi:10.1029/2004GL021034

Cas RAF, Wright JV (1987) Volcanic successions: modern and ancient. Allen \& Unwin, London, $528 \mathrm{p}$

Cashman KV (1988) Crystallization of Mount St. Helens 1980-1986 dacite: A quantitative textural approach. Bull Volcanol 50(3):194-209. doi:10.1007/BF01079682

Cashman KV (1992) Groundmass crystallization of Mount St. Helens dacite, 1980-1986: A tool for interpreting shallow magmatic processes. Contrib Mineral Petrol 109:431-449

Cashman KV (1993). Relationship between plagioclase crystallization and cooling rate in basaltic melts. Contrib Mineral Petr 113:126-142 
1312

1313

1314

1315

1316

1317

1318

1319

1320

1321

1322

1323

1324

1325

1326

1327

1328

1329

1330

1331

1332

1333

1334

1335

1336

1337

1338

1339

1340

1341

1342

Cashman KV, Marsh BD (1988) Crystal size distribution (CSD) in rocks and the kinetics and dynamics of crystallization II. Makaopuhi lava lake. Contrib Mineral Petrol 99:292-305

Cashman KV, McConnell S (2005) Transitions from explosive to effusive activity - the summer 1980 eruptions of Mount St. Helens. Bull Volcanol 68:57-75

Cashman KV, Mangan MT, Newman S (1994) Surface degassing and modifications to vesicle size distributions in Kilauea basalt. J Volcanol Geotherm Res 61:45-68

Castro JM, Cashman KV, Manga M (2003) A technique for measuring 3D crystal-size distributions of prismatic microlites in obsidian. Am Mineral 88:1230-1240

Castro JM, Burgisser A, Shipper CI, Mancini S (2012) Mechanisms of bubble coalescence in silicic magmas. Bull Volcanol 74:2339-2352

Chakraborty S (2008) Diffusion in solid silicates: A tool to track timescales of processes comes of age. Annu Rev Earth Planet Sci 36 (1):153-190

Chen Y, Provost A, Schiano P, Cluzel N (2011) The rate of water loss from olivine-hosted melt inclusions. Contrib Mineral Petrol 162:625-636

Chen Y, Provost A, Schiano P, Cluzel N (2013) Magma ascent rate and initial water concentration inferred from diffusive water loss from olivine-hosted melt inclusions. Contrib Mineral Petrol 165:525-541

Cheng HC, Lemlich R (1983) Errors in the measurement of bubble-size distribution in foam. Ind. Eng Chem Fundam 22:105-109

Chouet B, Hamisevicz N, McGetchin TR (1974) Photoballistics of volcanic jet activity at Stromboli, Italy. J Geophys Res 79:4961-4976 
Cichy SB, Botcharnikov RE, Holtz F, Behrens H (2011) Vesiculation and microlite

1344 crystallization induced by decompression: a case study of the 1991-1995 Mt Unzen eruption (Japan). J Petrol 52:1469-1492

Cigolini C, Laiolo M, Bertolino S (2008) Probing Stromboli volcano from the mantle to paroxysmal eruptions. In: Annen C, Zellmer GF (eds) Dynamics of crustal magma transfer, storage and differentiation. Geological Society, London, special publication, vol 304. Geological Society, London, pp 33-70

Cimarelli C, Di Traglia F, Taddeucci J (2010) Basaltic scoria textures from a zoned conduit as precursors to violent Strombolian activity. Geology 38(5): 439-442

Cioni R, D’Oriano C, Bertagnini A (2008) Fingerprinting ash deposits of small scale eruptions by their physical and textural features. J Volcanol Geotherm Res 177:277-287

Cioni R, Bertagnini A, Andronico D, Cole PD, Mundula F (2011) The 512 AD eruption of Vesuvius: complex dynamics of a small scale subplinian event. Bull Volcanol 73 (7):789-810. doi:10.1007/s00445-011-0454-3

Clarke AB, Stephens S, Teasdale R, Sparks RSJ, Diller K (2007) Petrologic constraints on the decompression history of magma prior to Vulcanian explosions at the Soufrière Hills volcano, Montserrat. J Volcanol Geotherm Res 161:261-274

Clarke AB, Phillips JC, Chojnicki KN (2009) An investigation of Vulcanian eruption dynamics using laboratory analogue experiments and scaling analysis. In: Studies in Volcanology: The Legacy of George Walker, Thordason T, Self S, Larsen G, Rowland SK, Höskuldsson Á (eds) IAVCEI Special Publications in Volcanology 2: 155-166.

Cluzel N, Laporte D, Provost A (2008) Kinetics of heterogeneous bubble nucleation in rhyolitic melts: implications for the number density of bubbles in volcanic conduits and for pumice textures. Contrib Mineral Petrol 156:745-763 
Colò L, Ripepe M, Baker DR, Polacci M (2010), Magma vesiculation and infrasonic activity at Stromboli open conduit volcano. Earth Planet Sc Lett 292 (3-4)

Colucci S, Palladino DM, Mulukutla GK, Proussevitch AA (2013) 3-D reconstruction of ash vesicularity: Insight into the origin of ash-rich explosive eruptions. J Volcanol Geotherm Res 255:98-107

Costa F, Cohmen R, Chakraborty S (2008) Time scales of magmatic processes from modeling the zoning patterns of crystals. In Putirka KD, Tepley FJ (Eds) Minerals, inclusions and volcanic processes. Rev Mineral Geochem 69:545-594

Costantini L, Houghton BF, Bonadonna C (2010) Constraints on eruption dynamics of basaltic explosive activity derived from chemical and microtextural study: the example of the Fontana Lapilli Plinian eruption, Nicaragua. J Volcanol Geother Res 189 (3-4):207-224. doi:10.1016/j.jvolgeores.2009.11.008

Couch S, Sparks RSJ, Carroll MR (2003) The kinetics of degassing-induced crystallization at Soufrière Hills Volcano, Montserrat. J Petrol 44(8):1477-1502

De Campos CP, Dingwell DB, Perugini D, et al. (2008) Heterogeneities in magma chambers: Insights from the behavior of major and minor elements during mixing experiments with natural alkaline melts. Chem Geol 256:131-145. doi: 10.1016/j.chemgeo.2008.06.034

De Keyser TL (1999) Digital scanning of thin sections and peels. J Sedim Res 69:962-964

Degruyter W, Bachmann O, Burgisser A (2010a) Controls on magma permeability in the volcanic conduit during the climactic phase of the Kos Plateau Tuff eruption (Aegean Arc). Bull Volcanol 72:63-74. doi: 10.1007/s00445-009-0302-x

Degruyter W, Burgisser A, Bachmann O, Malaspina O (2010b) Synchrotron X-ray microtomography and lattice Boltzmann simulations of gas flow through volcanic pumices. Geosphere 6:470-481 
Degruyter W, Bachmann O, Burgisser A, Manga M (2012) The effects of outgassing on the transition between effusive and explosive silicic eruptions. Earth Planet Sc Lett 349-350:161170

1411

Dehn J, Dean K, Engle K (2000) Thermal monitoring of North Pacific volcanoes from space. Geology 28(8):755-758

Dehn J, Dean KG, Engle K, Izbekov P (2002) Thermal precursors in satellite images of the 1999 eruption of Shishaldin volcano. Bull Volcanol 64:525-545

Delle Donne D, Ripepe M (2012) High-frame rate thermal imagery of Strombolian explosions: Implications for explosive and infrasonic source dynamics. J Geophys Res 117(B12). doi: 10.1029/2011JB008987

Dellino P, La Volpe L (1996a) Image processing analysis in reconstructing fragmentation and transportation mechanisms of pyroclastic deposits. the case of Monte Pilato-Rocche Rosse 1425 eruptions, Lipari (Aeolian Islands, Italy). J Volcanol Geotherm Res 71:13-29

Dellino P, Liotino G (2002) The fractal and multifractal dimension of volcanic ash particles contour: a test study on the utility and volcanological relevance J Volcanol Geotherm Res 113 (1-2):1-18. doi:10.1016/S0377-0273(01)00247-5

Dellino P, Isaia R, La Volpe L, Orsi G (2001) Statistical analysis of textural data from complex pyroclastic sequences: implications for fragmentation processes of the AgnanoMonte Spina Tephra (4.1 ka), Phlegraean Fields, southern Italy. Bull Volcanol 63:443-461

Dellino P, Mele D, Bonasia R, Braia G, La Volpe L, Sulpizio R (2005) The analysis of the influence of pumice shape on its terminal velocity. J Geophys Res 32:L21306. doi:10.1029/2005GL023954 
Dellino P, Mele D, Sulpizio R, La Volpe L, Braia G (2012) A method for the calculation of the impact parameters of dilute pyroclastic density currents based on deposit particle characteristics. J Geophys Res 113 (B7). doi 10.1029/2007JB005365

Denniss AM, Harris AJL, Rothery DA, Francis PW, Carlton RW (1998) Satellite observations of the April 1993 eruption of Lascar volcano. Int J Remote Sensing 19(5):801-821

Dixon JE (1997) Degassing of alkali basalts. Am Min 82:368-378

Dohmen R, Becker H-W, Chakraborty S (2007) Fe-Mg diffusion in olivine I: experimental determination between 700 and $1,200^{\circ} \mathrm{C}$ as a function of composition, crystal orientation and oxygen fugacity. Phys Chem 34:389-407. doi: 10.1007/s00269-007-0157-7

D’Oriano C, Poggianti E, Bertagnini A, Cioni R, Landi P, Polacci M, Rosi M (2005) Changes in eruptive styles during the A.D. 1538 Monte Nuovo eruption (Phleagrean Fields, Italy): the role of syneruptive crystallization. Bull Volcanol 67:601-621

D'Oriano C, Cioni R, Bertagnini A, Andronico D, Cole PD (2011a) Dynamics of ashdominated eruptions at Vesuvius: the post-512 AD AS1a event. Bull Volcanol 73 (6):699715. doi:10.1007/s00445-010-0432-1

D’Oriano C, Bertagnini A, Pompilio M (2011b) Ash erupted during normal activity at Stromboli (Aeolian Islands, Italy) raises questions on how the feeding system works. Bull Volcanol 73:471-477

D’Oriano C, Pompilio M, Bertagnini A, Cioni R, Pichavant M (2012) Effects of experimental reheating of natural basaltic ash at different temperatures and redox conditions. Contrib Mineral Petrol. doi: 10.1007/s00410-012-0839-0

Dubosclard G, Cordesses R, Allard P, Hervier C, Coltelli C, Kornprobst J (1999) First testing of a volcano Doppler radar (Voldorad) at Mount Etna, Italy. Geophys Rese Lett 26(22):33893392 
1474 Eichelberger JC, Carrigan CR, Westrich HR, Price RH (1986) Non-explosive silicic volcanism. Nature 323:598-602

Engwell SL, Sparks RSJ, Aspinall WP (2013) Quantifying uncertainties in the measurement of tephra fall thickness. J Applied Volcanol 2:5. doi:10.1186/2191-5040-2-5.

Ersoy O, Chinga G, Aydar E, Gourgaud A, Cubuku HE, Ulusoy I (2006) Texture discimination of volcanic ashes from different fragmenation mechanisms: A case study, Mount Nemrut stratovolcano, eastern Turkey. Comput Geosci 32:936-946

Eychenne J, Le Pennec JL, Troncoso L, Gouhier M, Nedelec JM (2012) Causes and consequences of bimodal grainsize distribution of tephra fall deposited during the August 2006 Tungurahua eruption (Ecuador). Bull Volcanol 74:187-205. doi: 10.1007/s00445-0110517-5

Eychenne J, Le Pennec JL, Ramón P, Yepes H (2013) Dynamics of explosive paroxysms at open-vent andesitic systems: High-resolution mass distribution analyses of the 2006 Tungurahua fall deposit (Ecuador). Earth Planet Sci Lett 361:343-355. doi: 10.1016/j.eps1.2012.11.002

Eychenne J, Houghton BF, Swanson DA, Carey RJ, Swavely L (2015) Dynamics of an open basaltic magma system: The 2008 activity of the Halema'uma'u Overlook vent, Kîlauea Caldera. Earth Planet Sci Lett 409:49-60

Fagents SA, Gregg TKP, Lopes RMC (2013) Modeling Volcanic Processes. The Physics and Mathematics of Volcanism. Cambridge University Press

Faure F, Trolliard G, Nicollet C, Montel J-M (2003) A developmental model of olivine morphology as a function of the cooling rate and the degree of undercooling. Contrib Mineral

Faure F, Schiano P, Trolliard G, Nicollet C, Soulestin B (2007) Textural evolution of polyhedral olivine experiencing rapid cooling rates. Contrib Mineral Petrol 153:405-416 
1508

1509

1510

1511

1512

1513

1514

1515

1516

1517

1518

1519

1520

1521

1522

1523

1524

1525

1526

1527

1528

1529

1530

1531

1532

1533

1534

1535

1536

1537

1538

1539

1540

1541

Ferguson DJ; Plank TA; Hauri EH; Houghton BF; Gonnermann HM; Swanson DA; Blaser AP (2013) Comparing eruptions of varying intensity at Kilauea via melt inclusion analysis. American Geophysical Union, Fall Meeting 2013, abstract \#V33F-07

Fierstein J, Nathenson M (1992) Another look at the calculation of fallout tephra volumes. Bull Volcanol 54:156-167

Fierstein J, Houghton BF, Wilson CJN, Hildreth W (1997) Complexities of plinian fall deposition at vent: an example from the 1912 Novarupta eruption (Alaska). J Volcanol Geotherm Res 76:215-227

Fischer TP (2008) Fluxes of volatiles (H2O, CO2, N2, Cl, F) from arc volcanoes. Geochem J 42:21-38. doi: 10.2343/geochemj.42.21

Fisher RV, Schmincke H-U (1984) Pyroclastic rocks. Springer, Berlin Heidelberg New York

Fiske RS, Rose TR, Swanson D, Champion D, McGeehin J (2009) Kulanaokuaiki Tephra (ca. A.D. 400-1000): Newly recognized evidence for highly explosive eruptions at Kîlauea Volcano, Hawai'i." GSA Bull 121:712-728

Formenti Y, Druitt TH (2003) Vesicle connectivity in pyroclasts and implications for the fluidisation of fountain-collapse pyroclastic flows, Montserrat (West Indies). Earth Planet Sci Lett 214:561-574

Freundt A, Rosi M (1998) From Magma to Tephra. Elsevier, New York

Friese K-I, Cichy SB, Wolter F-E, Botcharnikov RE (2013). Analysis of tomographic mineral data using YaDiV - Overview and practical case study. Comput Geosci 56:92-103

Gaonac'h H, Lovejoy S, Stix J, Schertzer D (1996a) A scaling growth model for bubbles in basaltic flows. Earth Planet Sci Lett 139:395-409

Gaonac'h H, Stix J, Lovejoy S (1996b) Scaling effects on vesicles shape, size and heterogeneity of lavas from Mount Etna. J Volcanol Geotherm Res 74:131-153 
1543 Gaonac'h H, Lovejoy S, Schertzer D (2003) Percolating magmas and explosive volcanism.

Gaonac'h H, Lovejoy S, Schertzer D (2005) Scaling vesicle distributions and volcanic eruptions. Bull Volcanol 67(4):350-357

Gardner JE (2007) Heterogeneous bubble nucleation in highly viscous silicate melts during instantaneous decompression from high pressure. Chem Geol 236:1-12

1551

Gaudin D, Moroni M, Taddeucci J, Scarlato P Shindler L. (2014a) Pyroclast Tracking Velocimetry: A particle tracking velocimetry-based tool for the study of Strombolian explosive eruptions. J Geophys Res Solid Earth 119:5369-5383. Doi:10.1002/2014JB011095

Gaudin D, Taddeucci J, Scarlato P, Moroni M, Freda C, Gaeta M, Palladino DM (2014b) Pyroclast Tracking Velocimetry illuminates bomb ejection and explosion dynamics at Stromboli (Italy) and Yasur (Vanuatu) volcanoes. J Geophys Res Solid Earth 119:5384-5397. doi:10.1002/2014JB011096

Genareau K, Proussevitch AA, Durant AJ, Mulukutla GK, Sahagian DL (2012) Sizing up the bubbles that produce very fine ash during explosive volcanic eruptions. Geophys Res Lett 39:(LI5306).

Genareau K, Mulukutla GK, Proussevitch AA, Durant AJ, Rose WI, Sahagian DL (2013) The size range of bubbles that produce ash during explosive volcanic eruptions. J Appl Volcanol 2:4. doi:10.1186/2191-5040-2-4

Genco R, Ripepe M (2010) Inflation-deflation cycles revealed by tilt and seismic records at Stromboli volcano. Geophys Res Lett 37. doi: 10.1029/2010GL042925

Gerst A, Hort M, Aster RC, Johnson JB, Kyle PR (2013) The first second of volcanic eruptions from the Erebus volcano lava lake, Antarctica-Energies, pressures, seismology, and infrasound. J Geophys Res 118:3318-3340. doi:10.1002/jgrb.50234 
1574 Ghiorso MS, Sack RO (1995) Chemical mass transfer in magmatic processes. IV. A revised 1575 and internally consistent thermodynamic model for the interpolation and extrapolation of 1576 liquid-solid equilibria in magmatic systems at elevated temperatures and pressures. Contrib 1577 Mineral Petrol 119:197-212

Giachetti T, Gonnermann HM (2013).Water in pumices: rehydration or incomplete degassing? Earth Planet Sci Lett 369-370:317-332

Giachetti T, Druitt TH, Burgisser A, Arbaret L, Galven C (2010) Bubble nucleation and growth during the 1997 Vulcanian explosions of Soufrière Hills Volcano, Montserrat. J Volcanol Geotherm Res 193 (3-4):215-231. doi:10.1016/j.jvolgeores.2010.04.001

Giachetti T, Burgisser A, Arbaret L, Druitt TH, Kelfoun K (2011) Quantitative textural analysis of Vulcanian pyroclasts (Montserrat) using multi-scale X-ray computed microtomography: comparison with results from 2D image analysis. Bull Volcanol 73 (9):1295-1309. doi:10.1007/s00445-011-0472-1

Goldstein P, Chouet B (1994) Array measurements and modeling of sources of shallow volcanic tremor at Kilauea Volcano, Hawaii. J Geophys Res 99(B2):2637-2652

Gonnermann HM, Houghton BF (2012) Magma degassing and fragmentation during the Plinian eruption of Novarupta, Alaska, 1912. Geochem Geophys Geosyst13:Q10009. doi: 10 $.1029 / 2012 \mathrm{GC} 004273$

Gonnermann HM, Manga M (2013) Dynamics of magma ascent in the volcanic conduit. In Modelling volcanic processes: the physics and mathematics of volcanism, ed. By S. Fagents, T.K.P. Gregg, R.M.C. Lopes. Cambridge University Press, New York, pp. 55-84

Goodchild JS, Fueten F (1998) Edge detection in petrographic images using the rotating polarizer stage. Comput Geosci 24:745-751

Gouhier M, Donnadieu F (2008) Mass estimations of ejecta from Strombolian explosions by 
1609 Gouhier M, Donnadieu F (2011) Systematic retrieval of ejecta velocities and gas fluxes at 1610 Etna volcano using L-Band Doppler radar. Bull Volcanol 73(9):1139-1145. doi:10.1007/s00445-011-0500-1

1612

Gualda GAR (2006) Crystal size distributions derived from 3D datasets: sample size versus uncertainties. J Petrol 47(6):1245-1254

Gualda GAR, Rivers M (2006) Quantitative 3D petrography using X- ray tomography: 1618 application to Bishop Tuff pumice clasts. J Volcanol Geotherm Res 154(1-2):48-62

Gualda GAR, Pamukcu AS, Claiborne LL, Rivers ML (2010b) Quantitative 3D petrography using X-ray tomography 3: documenting accessory phases with differential absorption tomography. Geosphere 6(6):782-792

1626

Gurioli L, Houghton B, Cashman K, Cioni R (2005) Complex changes in eruption dynamics and the transition between Plinian and phreatomagmatic activity during the 79AD eruption of Vesuvius. Bull Volcanol 67:144-159 doi: 10.1007/s00445-004-0368-4

Gurioli L, Harris AJL, Houghton BF, Polacci M, Ripepe M (2008) Textural and geophysical characterization of explosive basaltic activity at Villarrica volcano. J Geophys Res 113:B08206. doi:10.1029/2007JB005328

Gurioli L, Harris AJL, Colò L, Bernard J, Favalli M, Ripepe M, Andronico D (2013) Classification, landing distribution and associated flight parameters for a bomb field emplaced during a single major explosion at Stromboli, Italy. Geology 41 (5):559-562. doi 
Gurioli L, Colò L, Bollasina AJ, Harris AJL, Whittington A, Ripepe M (2014) Dynamics of strombolian explosions: inferences from inferences from field and laboratory studies of erupted bombs from Stromboli volcano. J Geophys Res 119. doi:10.1002/2013JB010355

Hamada M, Laporte D, Cluzel N, Koga KT (2010) Simulating bubble number density of rhyolitic pumices from Plinian eruptions: constraints from fast decompression experiments. Bull Volcanol 72:735-746

Hammer JE (2008). Experimental studies of the kinetics and energetics of magma crystallization. Rev Mineral Geochem 69:9-59

Hammer JE, Rutherford MJ (2002) An experimental study of the kinetics of decompressioninduced crystallization in silicic melt. J Geophys Res 107(B1). doi:10.1029/2001JB000281

Hammer JE, Cashman KV, Hoblitt RP, Newman S (1999) Degassing and microlite crystallization during pre-climactic events of the 1991 eruption of Mt. Pinatubo, Philippines. Bull Volcanol 60:355-380

Hammer JE, Sharp TG, Wessel P (2010) Heterogeneous nucleation and epitaxial crystal growth of magmatic minerals. Geology 38: 367-370.

Harris A (2013) Thermal Remote Sensing of Active Volcanoes: A User's Manual, Cambridge University Press: 728 p.

Harris AJL, Ripepe M (2007) Synergy of multiple geophysical approaches to unravel explosive eruption conduit and source dynamics - A case study from Stromboli. Chemie der Erde 67: 1-35.

Harris AJL, Ripepe M, Hort M (2004) Foreward. J Volcanol Geotherm Res 137(1-3):vii- viii. doi:10.1016/S0377-0273(04)00276-8

Harris AJL, Ripepe M, Hughes EE (2012) Detailed analysis of particle launch velocities, size distributions and gas densities during normal explosions at Stromboli. J Volcanol Geotherm Res 231-232:109-131 
Harris AJL, Delle Donne D, Dehn J, Ripepe M, Worden K (2013a) Volcanic plume and bomb field masses from thermal infrared camera imagery. Earth Planet Sci Lett 365:77-85. doi:

Harris AJL, Battaglia J, Donnadieu F, Gurioli L, Kelfoun K, Labazuy P, Sawyer G, Valade S,

Bombun M, Barra V, Delle Donne D, Lacanna G (2013b) Full bandwidth remote sensing for total parameterization of volcanic plumes. EOS 94 (37):321-322

Heiken G and Pitts DE (1975) Identification of eruption clouds with the landsat satellites. Bull

Heiken G, Wohletz KH (1985) Volcanic ash, University of California Press, Berkeley, Ca,

Heilbronner R (2000) Automatic grain boundary detection and grain size analysis using polarization micrographs or orientation images. J Struct Geol 22:969-981

Herd R, Pinkerton H (1997) Bubble coalescence in basaltic lava: its impact on the evolution of bubble populations. J Volcanol Geotherm Res 75:137-157

Higgins MD (2000) Measurement of crystal size distributions Am Mineral 85:1105-1116

Higgins MD (2002a) A crystal size-distribution study of the Kiglapait layered mafic intrusion,

Higgins MD (2002b) Closure in crystal size distributions (CSD), verification of CSD

Higgins MD (2006) Quantitative textural measurements in igneous and metamorphic petrology. Cambridge University Press, Cambridge 
Hoblitt RP, Harmon RS (1993) Bimodal density distribution of cryptodome dacite from the 1980 Mount St. Helens, Washington. Bull Volcanol 55:421- 437

Holasek RE, Self S (1995) GOES weather satellite observations and measurements of the May 18, 1980, Mount St. Helens eruption. J Geophys Res 100(B5):8469-8487

Holasek RE, Self S, Woods AW (1996) Satellite observations and interpretation of the 1991 Mount Pinatubo eruption plumes. J Geophys Res 101(B12):27635-27655

Holland ASP, Watson M, Phillips JC, Caricchi L, Dalton MP (2011) Degassing processes during lava dome growth: Insights from Santiaguito lava dome, Guatemala. J Volcanol Geotherm Res 202(1-2):153-166

Hort M, Seyfried R, Vöge M (2003) Radar Doppler velocimity of volcanic eruptions: Theoretical considerations and quantitative documentation of changes in eruptive behaviour at Stromboli volcano, Italy. Geophys J Int 154:515-532

Hort M, Seyfried R (1998) Volcanic eruption velocities measured with a micro radar. Geophys Res Lett 25:113-116

Horton K, Williams-Jones G, Garbeil H, Elias T, Sutton AJ, Mouginis-Mark P, Porter JN, Clegg S (2005) Real-time measurement of volcanic SO2 emissions: validation of a new UV correlation spectrometer (FLYSPEC). Bull Volcanol: doi 10.1007/s00445-005-0014-9

Houghton BF, Wilson CJN (1989) A vesicularity index for pyroclastic deposits. Bull Volcanol 51:451-462. doi:10.1007/BF01078811

Houghton BF, Carey RJ, Cashman KV, Wilson CJN, Hobden BJ, Hammer JE (2010) Diverse patterns of ascent, degassing, and eruption of rhyolite magma during the 1.8 ka Taupo eruption, New Zealand: Evidence from clast vesicularity, J Volcanol Geotherm Res 195:3147 
1740 Houghton BF, Swanson DA, Rausch J, Carey RJ, Fagents SA, Orr TR (2013) Pushing the 1741 Volcanic Explosivity Index to its limit and beyond: Constraints from exceptionally weak explosive eruptions at Kilauea in 2008. Geology 41(6):627-630

Humphreys MCS, Menand T, Blundy JD, Klimm K (2008a) Magma ascent rates in explosive eruptions: constraints from H2O diffusion in melt inclusions. Earth Planet Sci Lett 270:25-40

Humphreys MC, Blundy JD, Sparks RSJ (2008b) Shallow-level decompression crystallization and deep magma supply at Shiveluch volcano. Contrib Mineral Petrol 155:45-61

Hurwitz S, Navon O (1994) Bubble nucleation in rhyolitic melts: experiments at high pressure, temperature, and water content. Earth Planet Sci Lett 122:267-280

Iguchi M, Yakiwara H, Tameguri T, Hendrasto M, Hirabayashi J (2008) Mechanism of explosive eruption revealed by geophysical observations at the Sakurajima, Suwanosejima and Semeru volcanoes. J Volcanol Geotherm Res 178(1):1-9

Innocenti S, Andreastuti S, Furman T, del Marmol M-A, Voight B (2013) The pre-eruption conditions for explosive eruptions at Merapi volcano as revealed by crystal texture and mineralogy. J Volcanol Geother Res doi.org/10.1016/j.jvolgeores.2012.12.028

Ishibashi H, Sato H (2007) Viscosity measurements of subliquidus magmas: alkali olivine basalt from the Higashi-Matsuura district, Southwest Japan. J Volcanol Geotherm Res 160:223-238

Jerram DA, Cheadle MJ, Philpotts AR (2003) Quantifying the building blocks of igneous

Jouniaux L, Bernard ML, Zamora M, Pozzi JP (2000) Streaming potential in volcanic rocks volcanoes revealed by kinetic modeling, and the connection to monitoring data: An example 
1775 Kaneshima S, Kawakatsu H, Matsubayashi H, Sudo Y, Tsutsui T, Ohminato T, Ito H, Uhira 1776 K, Yamasato H, Oikawa J, Takeo M, Iidaka T (1996) Mechanism of phreatic eruptions at Aso 1777 Volcano inferred from near-field broadband seismic observations. Science 273(5275):643-645

Kennedy B, Spieler O, Scheu B, Kueppers U, Taddeucci J, Dingwell DB (2005) Conduit implosion during Vulcanian eruptions. Geology 33:581-584. doi: 10.1130/G21488.1

Kent AJR (2008) Melt inclusions in basaltic and related volcanic rocks. Rev Mineral

Kent AJR, Blundy J, Cashman K, Cooper KM, Donnelly C. et al. (2007) Vapor transfer prior

Ketcham RA (2005) Computational methods for quantitative analysis of three-dimensional features in geological specimens. Geosphere 1:32-41

Ketcham RA, Carlson WD (2001) Acquisition, optimization and interpretation of X-ray computed tomographic imagery: applications to the geosciences. Comput Geosci 27:381-400

Klawonn M, Houghton BF, Swanson DA, Fagents SA, Wessel P, Wolfe CJ (2014) Constraining explosive volcanism: subjective choices during estimates of eruption magnitude. Bull Volcanol 76:793. doi: 10.1007/s00445-013-0793-3

Klug C, Cashman KV (1994) Vesiculation of May 18, 1980, Mount St. Helens magma. Geology 22:468-472

Klug C, Cashman KV (1996) Permeability development in vesiculating magmas: implications for fragmentation. Bull Volcanol 58:87-100 
Koyaguchi T, Tokuno M (1993) Origin of the giant eruption cloud of Pinatubo, June 15, 1991. J Volcanol Geotherm Res 55:85-96

Krueger AJ, Walter LS, Doiron SD (1990) TOMS measurement of sulfur dioxide emitted during the 1985 Nevado del Ruiz eruptions. J Volcanol Geotherm Res 41:7-15

Kueppers U, Scheu B, Spieler O, Dingwell DB (2005) Field-based density measurements as tool to identify pre-eruption dome structure: set-up and first results from Unzen volcano, Japan. J Volcanol Geotherm Res 141:65-75

Kueppers U, Scheu B, Spieler O, Dingwell DB (2006) Fragmentation efficiency of explosive volcanic eruptions: A study of experimentally generated pyroclasts. J Volcanol Geotherm Res 153(1-2):125-135

Kyser TK, O’Neil JR (1984) Hydrogen isotope systematic of submarine basalts. Geochim Cosmochim Acta 48:2123-2133

Lak M, Néraudeau D, Nel A, Cloetens P, Perrichot V, Tafforeau P (2008) Phase contrast Xray synchrotron imaging: opening access to fossil inclusions in opaque amber. Microsc Microanal 14(3):251-259

Landi P, Marchetti E, La Felice S, Ripepe M, Rosi M (2011) Integrated petrochemical and geophysical data reveals thermal distribution of the feeding conduits at Stromboli volcano, Italy. Geophys Res Lett 38:L08305

Lanza R, Meloni A (2006) The Earth's magnetism: an introduction for geologists. 278 pp. Berlin, Heidelberg, New York: Springer-Verlag

Larsen JF (2008) Heterogeneous bubble nucleation and disequilibrium $\mathrm{H} 2 \mathrm{O}$ exsolution in Vesuvius K-phonolite melts. J Volcanol Geotherm Res 275:278-288

Larsen JF, Gardner JE (2000) Experimental constraints on bubble interactions in rhyolite melts: implications for vesicle size distributions. Earth Planet Sci Lett 180:201-214 
LaRue A, Baker DR, Polacci M, Allard P, Sodini N (2013), Can vesicle size distributions assess eruption intensity during volcanic activity? J Geophys Res-Solid Earth 4:373-80. doi:10.5194/se-4-373-2013

Laumonier M, Arbaret L, Burgisser A, Champallier R (2011) Porosity redistribution enhanced by strain localization in crystal-rich magmas. Geology 39:715-718. http://dx.doi.org/10.1130/G31803.1

Launeau P, Cruden AR (1998) Magmatic fabric acquisition mechanisms in a syenite: results of a combined anisotropy of magnetic susceptibility and image analysis study. J Geophys Res 103:5067-5089

1853

Launeau P, Bouchez JL, Benn K (1990) Shape preferred orientation of object populations: Automatic analysis of digitized images. Tectonophysics 180:201-211

Launeau P, Cruden AR, Bouchez JL (1994) Mineral recognition in digital images of rocks: a new approach using multichannel classification. Can Mineral 32:919-933

Lautze NC, Houghton BF (2005) Physical mingling of magma and complex eruption dynamics in the shallow conduit at Stromboli volcano, Italy. Geology 33:425-428.

Lautze NC, Houghton BF (2007) Linking variable explosion style and magma textures during 2002 at Stromboli volcano, Italy. Bull Volcanol 69:445-460

Lautze NC, Houghton BF (2008) Single explosions at Stromboli in 2002: use of clast microtextures to map physical diversity across a fragmentation zone. J Volcanol Geotherm Res 170:262-268 Castro D (2012) SEM-based methods for the analysis of basaltic ash from weak explosive activity at Etna in 2006 and the 2007 eruptive crisis at Stromboli. Phys Chem Earth 4546:113-127. doi:10.1016/j.pce.2011.02.001 

into explosion dynamics and the production of ash at Stromboli from samples collected in real time, October 2009. Geol S Am S 498:125-139

Lavallée Y, Varley N, Alatorre-Ibargüengoitia MA, Hess KU, Mueller S, Richard D, Scheu B, Spieler O, Dingwell DB (2012) Magmatic architecture of dome-building eruptions at Volcán de Colima, Mexico. Bull Volcanol 74:249-260

Leduc L, Gurioli L, Harris AJL, Colò L, Rose-Koga E Dynamics of a gas-dominated strombolian explosion. Bull Volcanol 77:8. doi: 10.1007/s00445-014-0888-5.

Le Losq C, Neuville DR, Moretti R, Roux J (2012) Determination of water content in silicate glasses using Raman spectrometry: Implications for the study of explosive volcanism. Am Mineral 97:779-790

Le Pennec JL, Hermitte D, Isya D, Pezard P, Coulon C, Cochemé J-J, Mulyadi E, Ollagnier F,Revest C (2001). Electrical conductivityand pore-space topology of Merapi lavas: implication for the degassing of porphyritic andesite magmas. Geophys Res Lett 28(22):4283-4286

Le Voyer M, Rose-Koga EF, Shimizu N, Grove TL, Schiano P (2010) Two contrasting $\mathrm{H}_{2} \mathrm{O}-$ rich components in primary melt inclusions from Mount Shasta. J Petrol 5(7):1571-1595. doi: 10.1093/petrology/egq030

Lesne P, Kohn SC, Blundy J, Witham F, Botcharnikov RE, Behrens H. (2011). Experimental simulation of closed-system degassing in the system basalt- $\mathrm{H}_{2} \mathrm{O}-\mathrm{CO}_{2}-\mathrm{S}-\mathrm{Cl}$. J Petrol 52:17371762

Liu Y, Anderson AT, Wilson CJN (2007) Melt pockets in phenocrysts and decompression rates of silicic magmas before fragmentation. J Geophys Res 112. doi:10.1029/2006JB004500 expansion-coalescence equation. J Geophys Res 109:B11203. doi:10.1029/2003JB002823 
Lumbreras F, Serrat J (1996) Segmentation of petrographical images of marbles. Comput Geosci 22:547-558

Magee C, O'Driscoll B, Chambers AD (2010) Crystallization and textural evolution of a closed-system magma chamber: insights from a crystal size distribution study of the Lilloise layered intrusion, east Greenland. Geol Mag 147:363-379

Manga M. (1998) Orientation distribution of microlites in obsidian. J Volcanol Geother Res $86: 107-115$

Mangan M (1990) Crystal size distribution systematics and the determination of magma storage times: The 1959 eruption of Kilauea volcano, Hawaii. J Volcanol Geother Res 44:295-302

Mangan MT, Cashman, KV (1996) The structure of basaltic scoria and reticulite and inferences for vesiculation, foam formation, and fragmentation in lava fountains. J Volcanol Geotherm Res 73:1-18

Mangan M, Sisson T (2000) Delayed, disequilibrium degassing in rhyolite magma: decompression experiments and implications for explosive volcanism. Earth Planet Sci Lett $183: 441-55$

Mangan M, Sisson T (2005). Evolution of melt-vapor surface tension in silicic volcanic systems: Experiments with hydrous melts. J Geophys Res 110:B01202. doi: 10.1029/2004JB003215

Mangan MT, Cashman KV, Newman S (1993) Vesiculation of basaltic magma during eruption. Geology 21:157-160

Marchetti E, Ripepe M, Harris AJL, Delle Donne D (2009) Tracing the differences between Vulcanian and Strombolian explosions using infrasonic and thermal radiation energy. Earth Planet Sci Lett 279:273-281 
Marchetti E, Poggi P, Bonadonna C, Pistolesi M, Hoskuldsson A (2013) Towards real-time measurements of tephra fallout grain-size distribution. MeMoVolc Meeting, Geneve Switzerland, Jannuary 2014

Maria A, Carey S (2002) Using fractal analysis to quantitatively characterize the shapes of volcanic particles. J Geophys Res 107:(B11):2283. doi:10.1029/2001JB000822

Maria A, Carey S (2007) Quantitative discrimination of magma fragmentation and pyroclastic transport processes using the fractal spectrum technique. J Volcanol Geotherm Res 161:234246

Marsh BD (1988) Crystal size distribution (CSD) in rocks and the kinetics and dynamics of crystallization: I. Theory. Contrib Mineral Petrol 99:277-291

Marsh BD (1998) On the interpretation of crystal size distributions in magmatic systems. J Petrol 39:553-599

Marsh BD (2007) Crystallization of silicate magmas deciphered using crystal size distributions. J Am Ceramic Society 90:746-757

Marshall JR (1987) Clastic particles: Scanning electron microscopy and shape analysis of sedimentary and volcanic clasts, Van Nostrand Reinhold Company, New York, 346 p.

Marschallinger R (1998a) A method for three-dimensional reconstruction of macroscopic features in geological materials. Comput Geosc 24:875-883

Marschallinger R (1998b) Correction of geometric errors associated with the 3-D reconstruction of geological materials by precision serial lapping. Mineral Mag 62:783-792

Marschallinger R (1998c) 3-D reconstruction and volume modelling of the grain fabric of geological materials. Phys Chem Earth 23:267-271 
Martel C (2012) Eruption Dynamics inferred from microlite crystallization experiments: application to Plinian and dome-forming eruptions of Mt. Pelée (Martinique, Lesser Antilles). J Petrol 53:699-725

Martel C, Radadi Ali A, Poussineau S, Gourgaud A, Pichavant M (2006) Basalt-inherited microlites in silicic magmas: evidence from Mt. Pelée (Martinique, F.W.I.). Geology 34:905908

Marti J, Soriano C, Dingwell DB (1999) Tube pumices as strain markers of the ductile-brittle transition during magma fragmentation. Nature 402(6762):650-653

Martí J, Castro A, Rodríguez C, Costa F, Carrasquilla S, Pedreira R, Bolos X (2013) Correlation of magma evolution and geophysical monitoring during the 2011-2012 El Hierro (Canary Islands) submarine eruption. J Petrology 54(7):1349-1373. doi:10.1093/petrology/egt014.

Mattsson HB (2010) Textural variation in juvenile pyroclasts from an emergent, Surteyantype, volcanic eruption: The Capelas tuff cone, São Miguel (Azores). J Volcanol Geoth Res $189: 81-91$

McNutt SR (1986) Observations and analysis of B-type earthquakes, explosions, and volcanic tremor at Pavlof Volcano, Alaska. Bull Seis Soc Amer 76:153-175

Mele D, Dellino P, Sulpizio R, Braia G (2011) A systematic investigation on the aerodynamics of ash particles, J Volcanol Geotherm Res 203:1-11. doi:10.1016/j.jvolgeores.2011.04.004

Melnik O, Sparks RSJ (2002) Dynamics of magma ascent and lava extrusion at Soufrière Hills Volcano, Montserrat. In: Druitt, T., Kokelaar, B. (Eds.), The Eruption of Soufrière Hills Volcano, Montserrat, from 1995 to 1999. The Geological Society of London, pp. 153-171.

Métrich N, Bertagnini A, Landi P, Rosi M (2001), Crystallization driven by decompression and water loss at Stromboli volcano (Aeolian Islands, Italy). J Petrol 42:1471-1490. doi:10.1093/petrology/42.8.1471 
Métrich N, Wallace PJ (2008) Volatile abundances in basaltic magmas and their degassing paths tracked by melt inclusions. In Putirka KD, Tepley FJ (Eds) Minerals, inclusions and volcanic processes Rev Mineral Geochem 69:363-402

2012

Métrich N, Bertagnini A, Di Muro A (2010) Conditions of magma storage, degassing and ascent at Stromboli: new insights into the volcano plumbing system with inferences on the

Miwa T, Toramaru A (2013) Conduit process in vulcanian eruptions at Sakurajima volcano, Japan: Inference from comparison of volcanich ash with pressure wave and seismic data. Bull Volcanol 75:685

Miwa T, Toramaru A, Iguchi M (2009) Correlations of volcanic ash texture with explosion earthquakes from vulcanian eruptions at Sakurajima volcano, Japan. J Volcanol Geotherm

Miwa T, Geshi N, Shinohara H (2013) Temporal variation in volcanic ash texture during a vulcanian eruption at the Sakurajima volcano, Japan. J Volcanol Geotherm Res 260:80-89

2031

Mock A, Jerram DA, Breitkreuz C (2003) Using quantitative textural analysis to understand the emplacement of shallow-level rhyolitic laccoliths a case study from the Halle volcanic complex, Germany. J Petrol 44:833-849

Moitra P, Gonnermann HM, Houghton BF, Giachetti T (2013) Relating vesicle shapes in 2038 (2007) Combining CSD and isotopic microanalysis: magma supply and mixing processes at 
Mori T, Burton M (2006) The SO2 camera: a simple, fast and cheap method for groundbased imaging of SO2 in volcanic plumes. Geophys Res Lett 33(L24804): doi:10.1029/2006GL027916

2046

Mori T, Burton M (2009) Quantification of the gas mass emitted during single explosions on

Stromboli with the SO2 imaging camera. J Volcanol Geotherm Res 188:395-400. doi:10.1016/j.jvolgeores.2009.10.005

2050

2051

Mori J, Patia H, McKee C, Itikarai I, Lowenstein P, De Saint Ours P, Talai B (1989) 2052 Seismicity associated with eruptive activity at Langila volcano, Papua New Guinea. J Volcanol Geotherm Res 38(3-4):243-255

2054

Mourtada-Bonnefoi CC, Laporte D (2002) Homogenous bubble nucleation in rhyolitic magmas: An experimental study on the effect of $\mathrm{H}_{2} \mathrm{O}$ and $\mathrm{CO}_{2}$. J Geophys Res 107:B4. doi:

Mourtada-Bonnefoi CC, Laporte D (2004) Kinetics of bubble nucleation in a rhyolitic melt: an experimental study of the effect of ascent rate. Earth Planet Sci Lett 218:521-537

Mueller S, Melnik O, Spieler O, Scheu B, Dingwell DB (2005) Permeability and degassing of dome lavas undergoing rapid decompression: An experimental determination Bull Volcanol 2065 67(6):526-538. doi:10.1007/s00445-004-0392-4

Mueller S, Scheu B, Spieler O, Dingwell DB (2008) Permeability control on magma fragmentation. Geology 36(5):399-402. doi:10.1130/G24605A.1

Muir DD, Blundy JD, Rust AC (2012) Multiphase petrography of volcanic rocks using 
Murtagh RM, White JDL (2013) Pyroclast characteristics of a subaqueous to emergent Surtseyan eruption, Black Point volcano, California. J Volcanol Geotherm Res 267:75:91

Murtagh RM, White JDL, Sohn YK (2011) Pyroclast textures of the Ilchulbong 'wet' tuff cone, Jeju Island, South Korea. J Volcanol Geotherm Res 201:385-396.

Nakamura K (2006) Textures of plagioclase microlite and vesicles within volcanic products of the 1914-1915 eruptions of Sakurajima Volcano, Kyushu, Japan. J Mineral Petrol Sci 101:178-198

Nakamura M, Otaki K, Takeuchi S (2008) Permeability and pore-connectivity variation of pumices from a single pyroclastic flow eruption: Implications for partial fragmentation. $J$ Vocanol Geotherm Res 176:302-314

Németh K (2010) Volcanic glass textures, shape characteristics and compositions of phreatomagmatic rock units from the Western Hungarian monogenetic volcanic fields and their implications for magma fragmentation. Cent Eur J Geosci 2:399-419

Neuberg J, Luckett R, Ripepe M, Braun T (1994) Highlights from a seismic broadband array on Stromboli volcano. Geophys Res Lett 21:749-752

Newman S, Lowenstern JB (2002) VolatileCalc: a silicate melt-H2O-CO2 solution model written in Visual Basic for Excel: Computers and Geosciences 28(5):597-604

Newman S, Epstein S, Stolper E (1988) Water, carbon dioxide, and hydrogen isotopes in glasses from the CA. 1340 A.D. eruption of the Mono Craters, California: constraints on degassing phenomena and initial volatile content. J Volcanol Geotherm Res 35:75-96

Nguyen CT, Gonnermann HM, Chen Y, Huber C, Maiorano AA, Gouldstone A, Dufek J (2013) Film drainage and the lifetime of bubbles. Geochem Geophys Geosyst 14:3616-3631

Nishimura T, McNutt SR (2008) Volcanic tremor during eruptions: temporal characteristics, scaling and estimates of vent radius. J Volcanol Geotherm Res 178:10-18 
2110

2111

2112

2113

2114

2115

2116

2117

2118

2119

2120

2121

2122

2123

2124

2125

2126

2127

2128

2129

2130

2131

2132

2133

2134

2135

2136

2137

2138

2139

2140

2141

2142

2143

Noguchi S, Toramaru A, Shimano T (2006) Crystallization of microlites and degassing during magma ascent: Constraints on the fluid mechanical behavior of magma during the Tenjo Eruption on Kozu Island, Japan. Bull Volcanol 68:432-449. doi 10.1007/s00445-005-0019-4

Noguchi S, Toramaru A, Nakada S (2008) Relation between microlite textures and discharge rate during the 1991-1995 eruptions at Unzen, Japan. J Volcanol Geotherm Res 175(12):141-155

O'Driscoll B, Donaldson CH, Troll VR, Jerram DA, Emeleus CH (2007) An origin for harrisitic and granular olivine in the rum layered suite, NW Scotland: a crystal size distribution study. J Petrol 48(2):253-270

Okumura S, Nakamura M, Tsuchiyama A (2006) Shear-induced bubble coalescence in rhyolitic melts with low vesicularity. Geophys Res Lett 33:L20316. doi:10.1029/2006GL027347

Okumura S, Nakamura M, Tsuchiyama A, Nakano T, Uesugi K (2008) Evolution of bubble microstructure in sheared rhyolite: Formation of a channel-like bubble network: J Geophys Res 113:B07208. doi: 10.1029/2007JB005362

Okumura S, Nakamura M, Uesugi K, Nakano T, Fujioka T (2013) Coupled effect of magma degassing and rheology on silicic volcanism. Earth Planet Sci Lett 362:163-170

Oppenheimer C, Scaillet B, Martin RS (2011) Sulfur degassing from volcanoes: source conditions, surveillance, plume chemistry and impacts, Rev Mineral Geochem 73:363-421. doi:10.2138/rmg.2011.73.13

Palladino DM, Taddeucci J (1998) The basal ash deposit of the Sovana Eruption (Vulsini Volcanoes, central Italy): the product of a dilute pyroclastic density current. J Volcanol Geotherm Res 87:233-254

Pamukcu AS, Gualda GAR (2010) Quantitative 3D petrography using X-ray tomography 2: combining information at various resolutions. Geosphere 6:775-781. doi.org/10.1130/GES00565.1 
Pamukcu AS, Gualda GAR, Anderson AT (2012) Crystallization stages of the Bishop Tuff magma body recorded in crystal textures in pumice clasts. J Petrol 63:589-609

Pardo $\mathrm{N}$ et al (2014a) Perils in distinguishing phreatic from phreatomagmatic ash; insights into the eruption mechanisms of the 6 August 2012 Mt. Tongariro eruption, New Zealand. J Volcanol Geotherm Res http://dx.doi.org/10.1016/j.jvolgeores.2014.05.001

Pardo N, Cronin SJ, Wright HMN, Schipper IC, Smith I, Stewart B (2014b) Pyroclast textural variation as an indicator of eruption column steadiness in andesitic Plinian eruptions at Mt. Ruapehu. Bull Volcanol 76:822

Patrick MR (2007) Dynamics of Strombolian ash plumes from thermal video: motion, 2158

Perugini D, Poli G, Properini N (2002) Morphometric analysis of magmatic enclaves: a tool for understanding magma vesiculation and ascent. Lithos 61:225-235

Perugini D, Valentini L, Poli G (2007) Insights into magma chamber processes from the analysis of size distribution of enclaves in lava flows: a case study from Vulcano Island (Southern Italy). J Volcanol Geotherm Res 166:193-203

Perugini D, Speziali A, Caricchi L, Kueppers U (2011) Application of fractal fragmentation theory to natural pyroclastic deposits: Insights into volcanic explosivity of the Valentano scoria cone (Italy). J Volcanol Geotherm Res 202(3-4):200-210

Pfeiffer T, Costa A, Macedonio G (2005) A model for the numerical simulation of tephra fall deposits. J Volcanol Geotherm Res 140:273-294

2173 Pickering G, Bull JM Sanderson DJ (1995) Sampling power-law distributions: Tectonophysics. 248:1-20. doi:10.1016/0040-1951(95)00030-Q 
2176 Pichavant M, Martel C, Bourdier JL, Scaillet B (2002) Physical conditions, structure, and 2177 dynamics of a zoned magma chamber: Mount Pelée (Martinique, Lesser Antilles Arc). J Geophys Res 107. doi:10.1029/2001JB000315

2179

Pichavant M, Costa F, Burgisser A, et al. (2007) Equilibration scales in silicic to intermediate magmas: implications for experimental studies. J Petrol 48:1955-1972. doi: 10.1093/petrology/egm045

Pichavant M, Carlo I, Rotolo SG, et al. (2013) Generation of CO2-rich melts during basalt magma ascent and degassing. Contrib Mineral Petr. doi: 10.1007/s00410-013-0890-5

Piochi M, Mastrolorenzo G, Pappalardo L (2005) Magma ascent and eruptive processes from textural and compositional features of Monte Nuovo pyroclastic products, Campi Flegrei, Italy. Bull Volcanol 67:663-678

Piochi M, Polacci M, De Astis G, Zanetti A, Mangiacapra A, Vannucci R, Giordano D (2008) Texture and composition from pumices and scoriae of the Campi Flegrei caldera (Italy): Implications on the dynamics of explosive eruptions. Geochem Geophys Geosyst 9:Q03013. doi:10.1029/2007GC001746

Pioli L, Erlund E, Johnson E, Cashman K, Wallace P, Rosi M, Delgado Granados H (2008) Explosive dynamics of violent strombolian eruptions: the eruption of Parícutin volcano 1943-

Pioli L, Pistolesi M, Rosi M (2014) Transient explosions at open-vent volcanoes: the case of

Pistolesi M, Rosi M, Pioli L, Renzulli A, Bertagnini A, Andronico D (2008), The paroxysmal explosion and its deposits, in The Stromboli Volcano: An Integrated Study of the 2002-2003 Washington, D. C. doi:10.1029/182GM26 
Pistolesi M, Delle Donne D, Pioli L, Rosi M, Ripepe M (2011) The 15 March 2007 explosive crisis at Stromboli volcano, Italy: assessing physical parameters through a multidisciplinary approach. J Geophys Res 116(B12). doi: 958 10.1029/2011JB008527

Platz T, Cronin SJ, Cashman KV, Stewart RB, Smith IEM (2007) Transition from effusive to explosive phases in andesite eruptions - A case-study from the AD1655 eruption of Mt. Taranaki, New Zealand. J Volcanol Geotherm Res 161:15-34

Polacci M, P Papale, M Rosi (2001) Textural heterogeneities in pumices from the climatic eruption of Mount Pinatubo, 15 June 1991, and implications for magma ascent dynamics. Bull Volcanol 63:83-97

Polacci M, Pioli L, Rosi M (2003) The Plinian phase of the Campanian Ignimbrite eruption (Phlegrean Fields, Italy): evidence from density measurements and textural characterization of pumice. Bull Volcanol 65:418-432

Polacci M, Corsaro R, Andronico D (2006a) Coupled textural and compositional characterization of basaltic scoria: Insights into the transition from Strombolian to fire fountain activity at Mount Etna, Italy. Geology 34(3):201-204. doi:10.1130/G223181.1

Polacci M, Baker DR, Mancini L, Tromba G, Zanini F (2006b) Three-dimensional investigation of volcanic textures by X-ray microtomography and implications for conduit processes. Geophys Res Lett 33(13):L13312. doi:10.1029/2006GL026241

Polacci M, Baker DR, Bai L, Mancini L (2008) Large vesicles record pathways of degassing at basaltic volcanoes. Bull Volcanol 70:1023-1029. doi:10.1007/s00445-007-0184-8

Polacci M, Baker DR, Mancini L, Favretto S, Hill RJ (2009a) Vesiculation in magmas from Stromboli and implications for normal Strombolian activity and paroxysmal explosions in basaltic systems. J Geophys Res 114:B01206. doi.org/10.1029/2008JB005672

Polacci M, Burton MR, La Spina A, Murè F, Favretto S, Zanini F (2009b) The role of syneruptive vesiculation on explosive basaltic activity at Mt. Etna, Italy. J Volcanol Geotherm Res 179:265-269 
2243 Polacci M, Mancini L, Baker DR (2010) The contribution of synchrotron X-ray computed microtomography to understanding volcanic processes. J Synchrotron Radiation 17:215-221

Polacci M, Baker DR, La Rue A, Mancini L (2012) Degassing behaviour of vesiculated basaltic magmas: an example from Ambrym volcano, Vanuatu Arc, and comparison to Stromboli, Aeolian Islands, Italy. J Volcanol Geotherm Res 233-234:55-64. doi: 10.1016/j.jvolgeores.2012.04.019

Polacci M, Bouvet de Maisonneuve C, Giordano D, Piochi M, Mancini L, Degruyter W, Bachmanng O (2014) Permeability measurements of Campi Flegrei pyroclastic products: An example from the Campanian Ignimbrite and Monte Nuovo eruptions. J Volcanol Geotherm Res 272:16-22

Prata AJ (1989) Infrared radiative transfer calculations for volcanic ash clouds. Geophys Res Lett 15(11):1293-1296

Prata AJ, Bernardo C (2009) Retrieval of volcanic ash particle size, mass and optical depth from a ground-based thermal infrared camera. J Volcanol Geotherm Res 186:91-107

Prejean SG, Brodsky EE (2011) Volcanic plume height measured by seismic waves based on a

Prior DJ (1999) Problems in determining the orientations of crystal misorientation axes, for small angular misorientations, using electron backscatter diffraction in the SEM. J Microsc $195: 217-225$

Prior DJ, Boyle AP, Brenker F, Cheadle MC, Day A, Lopez G, Peruzzo L, Potts GJ, Reddy S, Spiess R, Timms NE, Trimby P, Wheeler J, Zetterström L (1999) The application of electron backscatter diffraction and orientation contrast imaging in the SEM to textural problems in rocks. Am Mineral 84:1741-1759 
Prodi F, Caracciolo D, Adderio LP, Gnuffi M, Lanzinger E (2011) Comparative investigation

2275 of Pludix disdrometer capability as Present Weather Sensor (PWS) during the Wasserkuppe campaign. Atmos Res 99(1):162-173

2277

Proussevitch AA, Sahagian DL, Tsentalovich EP (2007a) Statistical analysis of bubble and crystal size distributions: formulations and procedures. J Volcanol Geotherm Res 164:95-111

Proussevitch AA, Sahagian DL, Carlson W (2007b) Statistical analysis of bubble and crystal size distributions: application to Colorado Plateau basalts. J Volcanol Geotherm Res 164:112126

Proussevitch AA, Mulukutla GK, Sahagian DL (2011) A new 3D method of measuring bubble size distributions from vesicle fragments preserved on surfaces of volcanic ash particles. Geosphere 7:1-8

Pyle M (1989) The thickness, volume and grainsize of tephra fall deposits. Bull Volcanol $51: 1-15$

2291

Pyle DM, Mather TA (2009) Halogens in igneous processes and their fluxes to the atmosphere and oceans from volcanic activity: A review: Chem Geol 263(1-4):110-121. doi: 10.1016/j.chemgeo.2008.11.013

Riley CM, Rose WI, Bluth GJS (2003) Quantitative shape measurements of distal volcanic ash. J Geophys Res 108:B10. doi: 10.1029/2001JB000818

Ripepe M, Braun T (1994) Air-wave phases in strombolian explosion-quake seismograms: a possible indicator for the magma level? Acta Vulcanol 5:201-206

Ripepe M, Marchetti E (2002) Array tracking of infrasonic sources at Stromboli volcano. Geophys Res Lett 29 (22):2076

Ripepe M, Ciliberto S, Della Schiava M (2001) Time constraints for modeling source 
Ripepe M, Harris AJL, Carniel R (2002). Thermal, seismic and infrasonic evidences of variable degassing rates at Stromboli volcano. J Volcanol Geotherm Res 118:285-297

Ripepe M, Poggi P, Braun T, Gordeev E (1996) Infrasonic waves and volcanic tremor at Stromboli. Geophys Res Lett 23:181-184

Ripepe M, Rossi M, Saccorotti G (1993) Image processing of explosive activity at Stromboli. J Volcanol Geotherm Res 54:335-351

Rix M, Valks P, Hao N, Loyola D, Schlager H, Huntrieser H, Flemming J, Koehler U, Schumann U, Inness A (2012) Volcanic SO2, BrO and plume height estimations using GOME-2 satellite measurements during the eruption of Eyjafjallajökull in May 2010. J Geophys Res 117:D00U19. doi:10.1029/2011JD016718

Robock A, Matson M (1982) Circumglobal transport of the El Chichon volcanic dust cloud. Science 221:195-197

Roggensack K, hervig RL, McKnight SB, Williams SN (1997) Explosive basaltic volcanism from Cerro Negro volcano: influence of volatiles on eruptive style. Science 277:1639-1642

Rose WI, Self S, Murrow PJ, Bonadonna C, Durant AJ, Ernst GGJ (2008) Nature and significance of small volume fall deposits at composite volcanoes: Insights from the October 14, 1974 Fuego eruption, Guatemala. Bull Volcanol 70(9):1043-1067

Rose-Koga EF, Koga K, Schiano P, Le Voyer M (2012) Mantle source heterogeneity for South Tyrrhenian magmas revealed by $\mathrm{Pb}$ isotopes and halogen contents of olivine-hosted melt inclusions. Chem Geol 334:266-279

Rosseel JB, White JDL, Houghton BF (2006) Complex bombs of phreatomagmatic eruptions: role of agglomeration and welding in vents of the 1886 Rotomahana eruption, Tarawera, New Zealand. J Geophys Res 111:B12205. doi:10.1029/2005JB004073 
Rosi M, Bertagnini A, Harris AJL, Pioli L, Pistolesi M, Ripepe M (2006) A case history of paroxysmal explosion at Stromboli: Timing and dynamics of the April 5, 2003 event. Earth Planet Sci Lett 243:594-606

Rotella MD, Wilson CJN, Barker SJ, Wright IC (2013) Novel origins of highly vesicular pumice in a distinctive non-explosive submarine eruptive style. Nature Geosci 6:129-132

Rotella MD, Wilson CJN, Barker SJ, Cashman KV, Houghton BF, Wright IC (2013) Bubble development in explosive silicic eruptions: insights from pyroclast vesicularity textures from Raoul volcano (Kermadec arc). Bull Volcanol 76:826

Rust AC, Cashman KV (2004) Permeability of vesicular silicic magma: inertial and hysteresis effects. Earth Planet Sci Lett 228:93-107, http://dx.doi.org/ 10.1016/j.eps1.2004.09.025

Rust AC, Cashman KV (2007) Multiple origins of pyroclastic obsidian and implications for changes in the dynamics of the 1300 BP eruption of Newberry Volcano, OR. Bull Volcanol $69: 825-845$

Rust AC, Cashman KV (2011) Permeability controls on expansion and size distributions of pyroclasts. J Geophys Res 116:B11202

Rust AC, Manga M, Cashman KV (2003) Determining flow type, shear rate and shear stress in magmas from bubble shapes and orientations. J Volcanol Geotherm Res 122:111-132

Ruth D, Calder E (2014) Plate tephra: Preserved bubble walls from large slug bursts during violent Strombolian eruptions. Geology 42(1):11-14, doi:10.1130/G34859.1

Rutherford MJ, Hill PM (1993) Magma ascent rates from amphibole breakdown: an experimental study applied to the 1980-1986 Mount St. Helens eruptions. J Geophys Res 98:19667-19685

Rutherford MJ, Devine JD (2003) Magmatic conditions and magma ascent as indicated by hornblende phase equilibria and reactions in the 1995-2002 Soufrière Hills magma. J Petrol 44:1433-1454 
2375 Rutherford MJ, Sigurdsson H, Carey S, Davis A (1985) The May 18, 1980 eruption of Mount

2376 St. Helens, 1. Melt compositions and experimental phase equilibria. J Geophys Res 90:2929$2377 \quad 2947$

Saar MO, Manga M (1999) Permeability-porosity relationship in vesicular basalts. Geophys Res Lett 26(1):111-114

Sable JE, Houghton BF, Del Carlo P, Coltelli M (2006) Changing conditions of magma ascent and fragmentation during the Etna $122 \mathrm{BC}$ basaltic Plinian eruption: evidence from clast microtextures. J Volcanol Geotherm Res 158:333-354

Sable JE, Houghton BF, Wilson CJN, Carey RJ (2009) Eruption mechanisms during the climax of the Tarawera 1886 basaltic Plinian eruption inferred from microtextural characteristics of the deposits, in Studies in Volcanology: The Legacy of George Walker, Spec. Publ. IAVCEI, vol. 2, pp. 129-154, Geol. Soc., London

Sahagian DL, Proussevitch AA (1998) 3D particle size distributions from 2D observations: stereology for natural applications. J Volcanol Geotherm Res 84:173-196

Sahetapy-Engel ST, Harris AJL. (2009) Thermal-image-derived dynamics of vertical ash plumes at Santiaguito volcano, Guatemala. Bull Volcanol 71:827-830. doi:10.1007/s00445-

Salisbury MJ, Bohrson WA, Clynne MA, Ramos FC, Hoskin P (2008) Multiple plagioclase crystal populations identified by crystal size distribution and in situ chemical data: implications for timescales of magma chamber processes associated with the 1915 eruption of Lassen Peak, CA. J Petrol 49:1755-1780

Saunders K, Blundy J, Dohmen R, Cashman (2012) Linking petrology and seismology at an active volcano. Science 336(6084):1023-1027. doi:10.1126/science.1220066 
Scaillet B, Evans BW (1999) The 15 June 1991 eruption of Mount Pinatubo. I. Phase equilibria and pre-eruption $P-T-f \mathrm{O}_{2}-f \mathrm{H}_{2} \mathrm{O}$ conditions of the dacite magma. J Petrol 40(3):381411

Schiavi F, Kobayashi K, Moriguti T, et al. (2010) Degassing, crystallization and eruption dynamics at Stromboli: trace element and lithium isotopic evidence from 2003 ashes. Contrib Mineral Petr 159:541-561

Schiavi F, Kobayashi K, Nakamura E, et al. (2012) Trace element and Pb-B-Li isotope systematics of olivine-hosted melt inclusions: insights into source metasomatism beneath Stromboli (southern Italy). Contrib Mineral Petrol 163:1011-1031

Schipper CI, White JDL, Houghton BF (2010a) Syn- and post-fragmentation textures in submarine pyroclasts from Loihi Seamount, Hawaii. J Volcanol Geotherm Res 191:93-106. doi:10.1016/j/jvolgeores.2010.01.002

Schipper CI, White JDL, Houghton BF, Shimizu N, Stewart RB (2010b) Explosive submarine eruptions driven by volatile-coupled degassing at Lo ihi Seamount, Hawai'i. Earth Planet Sci Lett 295(3-4):497-510

Schipper CI, White JDL, Houghton BF, Shimizu N, Stewart RB (2010c) "Poseidic" explosive eruptions at Loihi Seamount, Hawaii. Geology 38(4):291-294

Schipper CI, White JDL, Houghton BF (2011) Textural, geochemical, and volatile evidence for a Strombolian-like eruption sequence at Lō'ihi Seamount, Hawai i. J Volcanol Geotherm Res 207:16-32

Schipper CI, White JDL, Nichols ARL, Burgisser A, Hellebrand E, Murtagh RM (2012) Incipient melt segregation as preserved in subaqueous pyroclasts. Geology 40(4):355-358

Schipper CI, Castro JM, Tuffen H, James MR, How P (2013) Shallow vent architecture during hybrid explosive-effusive activity at Cordón Caulle (Chile, 2011-12): evidence from direct observations and pyroclast textures. J Volcanol Geotherm Res 262:25-37 
Sciotto M, Cannata A, Di Grazia G, Gresta S, Privitera E, Spina L (2011) Seismoacoustic investigations of paroxysmal activity at Mt. Etna volcano: New insights into the 16 November 2006 eruption. J Geophys Res 116. doi: 10.1029/2010JB008138

2443

Shea T, Larsen JF, Gurioli L, Hammer JE, Houghton BF, Cioni R (2009) Leucite crystals: surviving witnesses of magmatic processes preceding the $79 \mathrm{AD}$ eruption at Vesuvius, Italy. Earth Planet Sci Lett 281:88-98

Shea T, Houghton BF, Gurioli L, Cashman KV, Hammer JE, Hobden B (2010a) Textural studies of vesicles in volcanic rocks: an integrated methodology. J Volcanol Geotherm Res 190:271-289

Shea T, Gurioli L, Larsen JF, Houghton BF, Hammer JE, Cashman KV (2010b) Linking experimental and natural vesicle textures in Vesuvius 79 AD white pumice. J Volcanol Geotherm Res 192:69-84

Shea T, Gurioli L, Houghton BF, Cashman KV, Cioni R (2011) Column collapse and generation of pyroclastic density currents during the A.D. 79 eruption of Vesuvius: the role of pyroclast density. Geology 39:695-698

Shea T, Gurioli L, Houghton BF (2012) Transitions between fall phases and pyroclastic density currents during the AD 79 eruption at Vesuvius: building a transient conduit model from the textural and volatile record. Bull Volcanol 74:2363-2381. doi 10.1007/s00445-012$0668-\mathrm{z}$

Sheridan MF, Marshall JR (1983) Interpretation of pyroclast surface features using SEM 2471 images. J Volcanol Geotherm Res 16:153-159

Shea T, Hellebrand E, Gurioli L, Hugh T (2014) Conduit- to localized-scale degassing during Plinian eruptions: Insights from major element and volatile $\left(\mathrm{Cl}\right.$ and $\left.\mathrm{H}_{2} \mathrm{O}\right)$ analysis within Vesuvius AD79 pumice. J Petrol. doi:10.1093/petrology/egt069

Sheridan MF, Marshall JR (1987) Comparative charts for quantitative analysis of graintextural elements on pyroclasts, in Clastic Particles: Scanning Electron Microscopy And 
Shape Analysis Of Sedimentary And Volcanic Particles, edited by J. R. Marshall, Van Nostrand Reinhold Company, New York

Shimano T, Nakada S (2006) Vesiculation path of ascending magma in the 1983 and the 2000 eruptions of Miyakejima volcano, Japan. Bull Volcanol 68:549-566. doi: 10.1007/s00445005-0029-2

Shimano T, Nishimura T, Chiga N, Shibasaki Y, Iguchi M, Miki D and Yokoo A (2013) Development of an automatic volcanic ash sampling apparatus for active volcanoes. Bull Volcanol 75:73. doi: 10.1007/s00445-013-0773-7

Shin H, Lindquist WB, Sahagian DL, Song S-R (2005) Analysis of the vesicular structure of basalts. Comput Geosci 31(4):473-487. doi:10.1016/j.cageo.2004.10.013

Simakin AG, Bindeman IN (2008). Evolution of crystal sizes in the series of dissolution and precipitation events in open magma systems. J Volcanol Geotherm Res 17:997-1010

Simkin T, Howard KA (1970) Caldera Collapse in the Galápagos Islands, 1968 The largest known collapse since 1912 followed a flank eruption and explosive volcanism within the caldera. Science 169(3944):429-437

Sonder I, Graettinger A, Valentine G (2013) Large-scale blast experiments examine subsurface explosions. EOS Trans AGU 94(39):337-338. doi:10.1002/2013EO390002

Song SR, Jones KW, Lindquist WB, Dowd BA, Sahagian DL (2001) Synchrotron X-ray computed microtomography: studies on vesiculated basaltic rocks. Bull Volcanol 63(4):252263. doi:10.1007/s004450100141

Sottili G, Taddeucci J, Palladino DM, Gaeta M, Scarlato P, Ventura G (2009) Subsurface dynamics and eruptive styles of maars in the Colli Albani Volcanic District, Central Italy. J Volcanol Geotherm Res 180:189-202 
Sottili G, Taddeucci J, Palladino DM (2010) Constraints on magma-wall rock thermal interaction during explosive eruptions from textural analysis of cored bombs. J Volcanol Geotherm Res 192:27-34

2509

Sparks RSJ (1978) The dynamics of bubble formation and growth in magmas. J Volcanol

Geotherm Res 3:1-37. doi:10.1016/0377-0273(78)90002-1

Sparks RSJ, Brazier S (1982) New evidence for degassing processes during explosive eruptions. Nature 295:218-220

2515

2516

Sparks RSJ, Burski MI, Carey SN, Gilbert JS, Glaze LS, Sigurdsson H, Woods AW (1997) Volcanic Plume. John Wiley \& Sons, New York

2518

Spillar V, Dolejs D (2013) Calculation of time-dependent nucleation and growth rates from 2520 quantitative textural data: inversion of crystal size distribution. $J$ Petrol. doi:10.1093/petrology/egs091

2522

Stovall WK, Houghton BF, Gonnermann HM, Fagents S.A, Swanson DA (2011) Eruption dynamics of Hawaiian-style fountains: The case study of episode 1 of the Kîlauea Iki 1959 eruption. Bull Volcanol 73:511-529. doi:10.1007/s00445-010-0426-Z

Stovall WK, Houghton BF, Hammer JE, Fagents SA, Swanson DA (2012) Vesiculation of high fountaining Hawaiian eruptions: Episodes 15 and 16 of 1959 Kīlauea Iki. Bull Volcanol 74:441-455. doi:10.1007/s00445-011-0531-7

2530

Streck MJ (2008) Mineral textures and zoning as evidence for open system processes. In Putirka KD, Tepley FJ (Eds) Minerals, inclusions and volcanic processes. Rev Mineral Geochem 69:595-622

Suzuki Y, Nakada S (2001) Timing of vesiculation and crystallization during magma ascent Example of the phreatomagmatic phase in Usu 2000 eruption. Bull Earthq Res Inst 76:253- 
2539

Suzuki Y, Nakada S (2002) Vesiculation and magma ascent process in the Usu 2000 eruption, inferred from texture and size distribution of bubbles. Bull Volcanol Soc Japan 47:675-688

Swanson DA, Wooten K, Orr T (2009) Buckets of ash track tephra flux from Halema'uma'u crater, Hawaii. Eos Trans AGU 90:427-428. doi:10.1029/2009EO460003

Szramek L, Gardner JE, Larsen J. (2006) Degassing and microlite crystallization of basaltic andesite magma erupting at Arenal Volcano, Costa Rica. J Volcanol Geotherm Res 157:182201

Taddeucci J, Pompilio M, Scarlato P (2002) Monitoring the explosive activity of the JulyAugust 2001 eruption of Mt. Etna (Italy) by ash characterization. Geophys Res Lett 29(8):1029-1032. doi:10.1029/2001GL014372

Taddeucci J, Pompilio M, Scarlato P (2004) Conduit processes during the July-August 2001 explosive activity of Mt. Etna (Italy): inferences from glass chemistry and crystal size distribution of ash particles. J Volcanol Geotherm Res 137:33-54

Taddeucci J, Scarlato P, Capponi A, Del Bello E, Cimarelli C, Palladino D, Kueppers U (2012) High-speed imaging of Strombolian explosions: The ejection velocity of pyroclasts. Geophys Res Lett 39(2)

Takeuchi S, Nakashima S (2005) A new simple gas permeameter for permeability measurement of small samples of volcanic eruptive material and experimental run products (in Japanese with English abstract). Bull Volcanol Soc Jpn 50:1-8

Takeuchi S, Nakashima S, Akihiko Tomiya A (2008) Permeability measurements of natural and experimental volcanic materials with a simple permeameter: toward an understanding of magmatic degassing processes. J Volcanol Geotherm Res 177:329-339. http://dx.doi.org/10.1016/j.jvolgeores.2008.05.010.

Tarquini S, Favalli M (2010) A microscopic information system (MIS) for petrographic analysis. Comput Geosci 36:665-674 
2573 Thomas N, Jaupart C, Vergniolle S (1994) On the vesicularity of pumice. J Geophys Res 99:15633-15644

2575

Thomas HE, Watson IM, Carn SA, Alfredo AJ, Prata F, Realmuto VJ (2011) A comparison of AIRS, MODIS and OMI sulphur dioxide retrievals in volcanic clouds. Geomatics, Nat Hazards Risk 2(3):217-232

Thordarson T, Self S, Larsen G, Rowland SK, Hoskuldsson A (2009) Studies in Volcanology: the Legacy of George Walker. GSL Special Publication

2582

Toramaru A (1989) Vesiculation process and bubble size distribution in ascending magmas with constant velocities. J Geophys Res 94(1):523-17,542. doi:10.1029/JB094iB12p17523

Toramaru A (1990) Measurement of bubble size distributions in vesiculated rocks with implications for quantitative estimates of eruption processes. J Volcanol Geotherm Res 43:7190

Toramaru A (2006) BND (bubble number density) decompression rate meter for explosive volcanic eruptions J Volcanol Geotherm Res 154:303-316

Toramaru A, Noguchi S, Oyoshihara S, Tsune A (2008) MND (microlite number density)

Tsukui M, Suzuki Y (1995) Vesiculation of basaltic magma: magmatic versus phreatomagmatic eruption in 1983 eruption of Miyakejima. Bull Volcanol Soc Jpn 40, 395-

Valade S, Donnadieu F (2011) Ballistics and ash plumes discriminated by Doppler radar. 2602 Geophys Res Lett 38:L22301. doi:10.1029/2011GL049415 
2607

Villemant B, Boudon G (1998) Transition between dome-forming and plinian eruptive styles: H20 and CL degassing behaviour. Nature 392:65-69

Vinkler AP, Cashman K, Giordano G, Groppelli G (2012) Evolution of the mafic Villa Senni caldera-forming eruption at Colli Albani volcano, Italy, indicated by textural analysis of juvenile fragments. J Volcanol Geotherm Res 235-236:37-54

Vlastélic I, Staudacher T, Bachèlery P, Télouk P, Neuville D, Benbakkar M (2011) lithium isotope fractionation during magma degassing: constraints from silicic differentiates and natural gas condensates from Piton de la Fournaise volcano (Réunion Island). Chem Geol 284:26-34

Voltolini M, Zandomeneghi D, Mancini L, Polacci M (2011) Texture analysis of volcanic rock samples: Quantitative study of crystals and vesicles shape preferred orientation from X-ray microtomography data. J Volcanol Geot Res 202:83-95

Vöge M, Hort M, Seyfried R (2005) Monitoring volcano eruptions and lava domes with Doppler radar. EOS Trans AGU 86:537-541

Walker JC, Carboni E, Dudhia A, Grainger RG (2012) Improved detection of sulphur dioxide in volcanic plumes using satellite-based hyperspectral infrared measurements: Application to the Eyjafjallajökull 2010 eruption. J Geophys Res 117:D00U16. doi:10.1029/2011JD016810

Wallace PJ (2001) Volcanic $\mathrm{SO}_{2}$ emissions and the abundance and distribution of exsolved gas in magma bodies. J Volcanol Geotherm Res 108:85-106

Wallace PJ (2005) Volatiles in subduction zone magmas: concentrations and fluxes based on melt inclusion and volcanic gas data. J Volcanol Geotherm Res 140:217-240

Watson IM, Realmuto VJ, Rose WI, Prata AJ, Bluth GJS, Gu Y, Bader CE, Yu T (2004) Thermal infrared remote sensing of volcanic emissions using the moderate resolution imaging spectroradiometer. J Volcanol Geotherm Res 135:75-89 
2640 Wen S, Rose WI (1994) Retrieval of sizes and total masses of particles in volcanic clouds using AVHRR bands 4 and 5. J Geophys Res: Atmospheres 99(D3):5421-5431

2642

2643

White JDL, Houghton BF (2006) Primary volcaniclastic rocks. Geology 34:677-680. doi:10.1130/G22346.1

Whitham AG, Sparks RSJ (1986) Pumice. Bull Volcanol 48:209-223

Wilhelm S, Worner, G (1996) Crystal size distribution in Jurassic Ferrar flows and sills

(Victoria Land, Antarctica): Evidence for processes of cooling, nucleation, and crystallisation.

Williams-Jones G, Stix J, Hickson C (2008) The COSPEC cookbook. IAVCEI: Methods in

Volcanology I: 233 p.

Wilson L, Huang TC (1979) The influence of shape on the atmospheric settling velocity of volcanic ash particles. Earth Planet Sci Lett 44:311-324

Wilson L, Self S (1980) Volcanic explosion clouds: density, temperature and particle content estimates from cloud motion. J Geophys Res 85:2567-2572

Wright HMN, Weinberg R (2009) Strain localization in vesicular magma: Implications for rheology and fragmentation. Geology 37:1023-1026. doi:10.1130/G30199A.1

Wright HMN, Cashman KV (2014) Compaction and gas loss in welded pyroclastic deposits as revealed by porosity, permeability, and electrical conductivity measurements of the Shevlin Park Tuff. GSA Bulletin 126(1/2):234-247. doi: 10.1130/B30668.1

Wright HMN, Roberts JJ, Cashman KV (2006) Permeability of anisotropic tube pumice: model calculations and measurements. Geophys Res Lett 33:L17316. doi.org/10.1016/j.eps1.2009.01.023 
2672 Wright HMN, Cashman KV, Rosi M, Cioni R (2007) Breadcrust bombs as indicators of 2673 Vulcanian eruptiondynamics at Guagua Pichincha volcano. Ecuador. Bull Volcanol 69: 2812674300

Wright HMN, Cashman KV, Gottesfeld EH, Roberts JJ (2009) Pore structure of volcanic clasts: Measurements of permeability and electrical conductivity. Earth Planet Sci Lett 280:93-104. doi.org/10.1016/j.eps1.2009.01.023

Wright HMN, Folkes CB, Cas RAF, Cashman KV (2011) Heterogeneous pumice populations 2681 in the 2.08-Ma Cerro Galán Ignimbrite: implications for magma recharge and ascent preceding a large-volume silicic eruption. Bull Volcanol 73:1513-1533

Wright HMN, Cashman KV, Mothes PA, Hall ML, Ruiz AG, Le Pennec J-L (2012) Estimating 2685 rates of decompression from textures of erupted ash particles produced by 1999-2006 eruptions of Tungurahua Volcano, Ecuador. Geology 40:619-622. doi:10.1130/G32948

Wohletz K (1983) Mechanisms of hydrovolcanic pyroclast formation: grainsize, scanning 2689 electron microscopy, and experimental studies. J Volcanol Geother Res 17:31-63

2690

Wohletz K (1986) Explosive magma-water interactions: thermodynamics, explosion mechanisms, and field studies. Bull Volcanol 48:245-264

Wohletz K (1987) Chemical and textural surface features of pyroclasts from hydrovolcanic eruption sequences. In: Marsall, J.R. (Ed.), Clastic Particles. Van Nostrand Reinhold Co, New York, N.Y., pp. 79-97

Yang K, Krotkov NA, Krueger AJ, Carn SA, Bhartia PK, Levelt PF (2007) Retrieval of large volcanic SO2 columns from the Aura Ozone Monitoring Instrument (OMI): comparison and 2701 liquid. Earth Planets Space 60:1-19 
Yokoyama T, Takeuchi S (2009) Porosimetry of vesicular volcanic products by a waterexpulsion method and the relationship of pore characteristics to permeability. J Geophys Res 114:B02201. http://dx.doi.org/10.1029/2008JB005758.

2708

Yoshimoto M, Shimano T, Nakada S, Koyama E, Tsuji H, Iida A, Kurokawa M, Okayama Y, Nonaka M, Kaneko T, Hoshizumi H, Ishizuka Y, Furukawa R, Nogami K, Onizawa S, Niihori K, Sugimoto T, Nagai M (2005) Mass estimation and characteristics of ejecta from the 2004 eruption of Asama volcano. Bull Volcanol, Soc Jpn 50:519-533 (In Japanese with English abstract)

2714

Zandomeneghi D, Voltolini M, Mancini L, F. Brun, D. Dreossi, M. Polacci (2010) Quantitative analysis of X-ray microtomography images of geomaterials: Application to volcanic rocks, Geosphere, special issue "Advances in 3D Imaging and Analysis of Geomaterials" 6:793-804. doi:10.1130/GES00561.1.

Zakšek K, Hort M, Zaletelj J, Langmann B (2013) Monitoring volcanic ash cloud top height through simultaneous retrieval of optical data from polar orbiting and geostationary satellites. Atmos Chem Phys 13(5):2589-2606

Zimanowski B, Wohletz K, Dellino P, Buttner R (2003) The volcanic ash problem J. Volcanol.

Geotherm. Res. 122:1-5

Zobin VM, Santiago-Jiménez H, Ramírez-Ruiz JJ, Reyes-Dávila GA, Bretón-González M, Navarro-Ochoa C (2007) Quantification of volcanic explosions from tilt records: Volcán de Colima, México. J Volcanol Geotherm Res 166(2):117-124

\section{Figure captions}

Figure 1 Diagrammatic illustration showing a volcanic strombolian conduit (modified from Harris and Ripepe 2007), and the list of a few parameters that can be measuremed trought the deposit (D), the texture of the pyroclasts $(T)$, the geochemistry $(\mathrm{G})$ and the geophysics $(\mathrm{G})$ methods for small, magmatic explosions. 
Volume

Dispersion Magma discharge rate

Total grain size Total componentry Particle morphology Mass Mass load Plume quantification

\section{DEPOSITS}

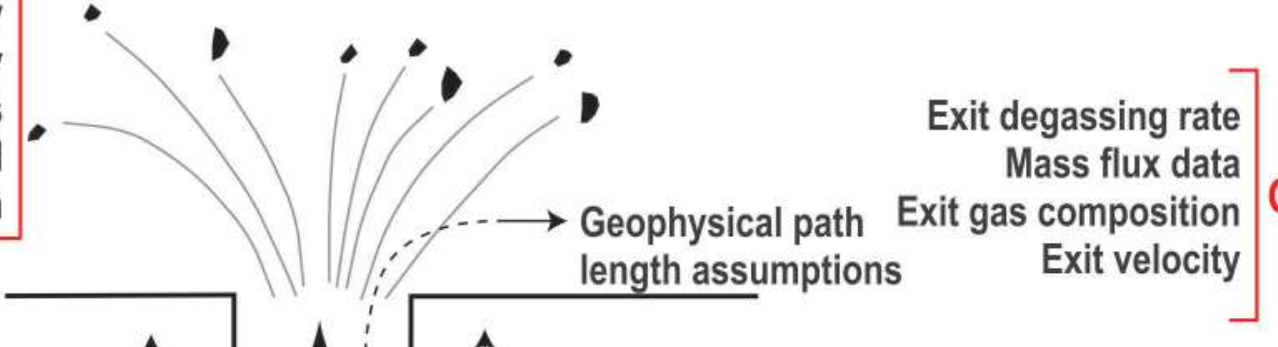

GEOPHYSICS

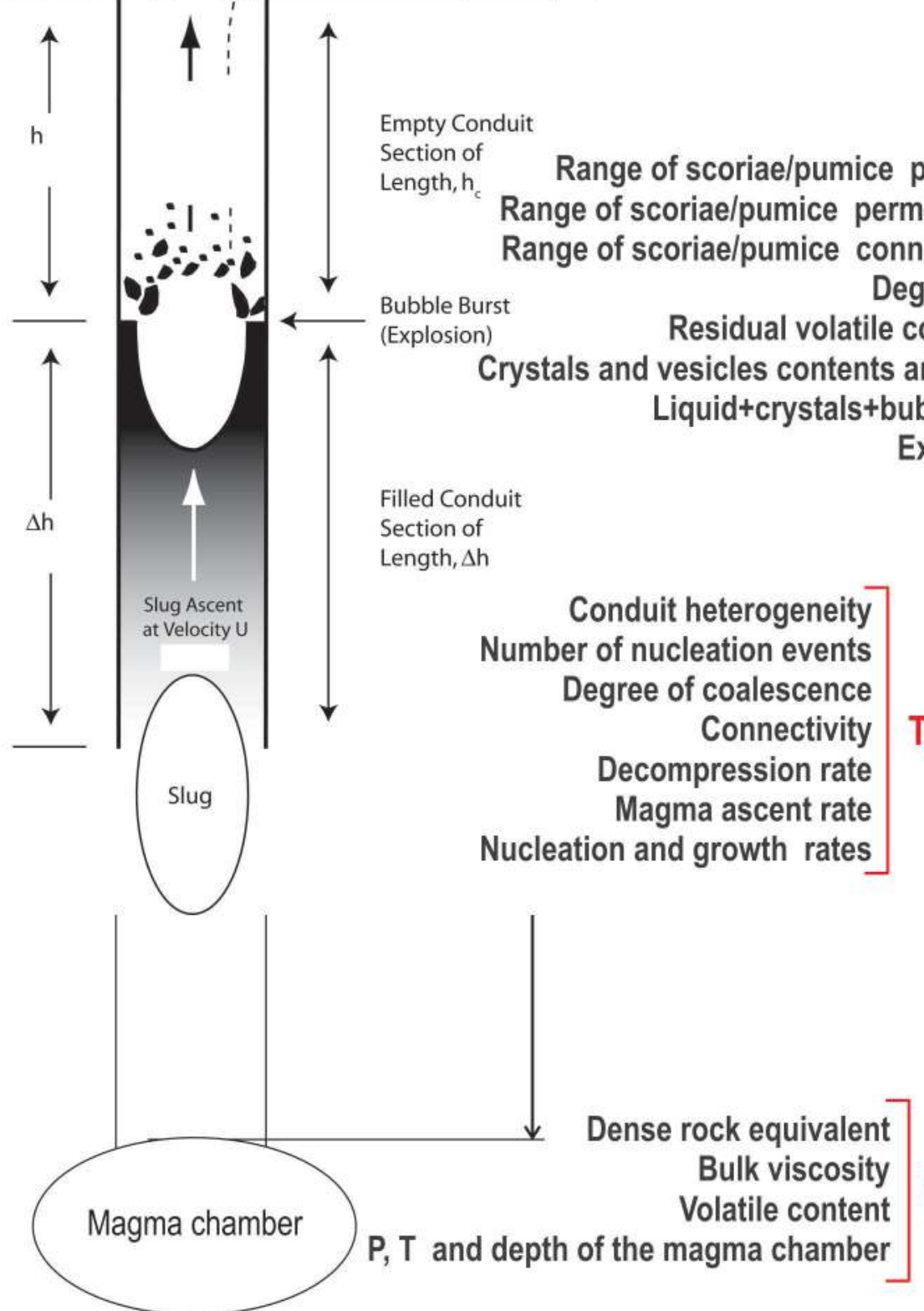

GEOCHEMISTRY 
Table 1 Quantification of explosive dynamics from textural parameters of the pyroclast components

\begin{tabular}{|c|c|c|c|}
\hline Textural parameters & \multicolumn{2}{|r|}{ Quantification } & References \\
\hline \multirow{4}{*}{$\begin{array}{l}\text { Clast shape, morphology } \\
\text { and size }\end{array}$} & \multicolumn{2}{|c|}{ Discriminate between different fragmentation mechanisms } & $\begin{array}{l}\text { Wohletz 1983; 1986; 1987; } \\
\text { Heiken and Wohletz 1985; } \\
\text { Sheridan and Marshall 1983; 1987; } \\
\text { Dellino and La Volpe 1996a; b; } \\
\text { Palladino and Taddeucci 1998; } \\
\text { Büttner et al. 1999; 2002; } \\
\text { Kueppers et al. 2006; } \\
\text { Dellino et al. 2001; 2012; } \\
\text { Zimanowski et al. 2003 } \\
\text { Németh 2010 } \\
\text { Pardo et al. 2014a }\end{array}$ \\
\hline & \multicolumn{2}{|c|}{ Conduit stratigraphy and processes } & $\begin{array}{l}\text { Taddeucci et al. 2002; } \\
\text { D'Oriano et al. 2005; } \\
\text { Cioni et al. 2011; } \\
\text { Perugini et al. 2011; } \\
\text { Andronico et al. 2009b; 2013a; } \\
\text { Lautze et al. 2012; 2013; } \\
\text { Perugini et al. 2002;2007 }\end{array}$ \\
\hline & \multicolumn{2}{|c|}{ State of the magma at the fragmentation } & $\begin{array}{l}\text { Carey et al. 2000; } \\
\text { Dellino and Liotino 2002; } \\
\text { Maria and Carey 2002; 2007; } \\
\text { D'Oriano et al. 2011; } \\
\text { Ruth and Calder } 2014\end{array}$ \\
\hline & \multicolumn{2}{|c|}{$\begin{array}{l}\text { Link between vesicularity and particle morphology, and particle } \\
\text { morphology with cloud dispersal and sedimentation }\end{array}$} & $\begin{array}{l}\text { Wilson and Huang } 1979 ; \\
\text { Dellino et al. 2005; } \\
\text { Mattsson } 2010 \\
\text { Alfano et al. } 2011 ; \\
\text { Mele et al. } 2011\end{array}$ \\
\hline \multirow{3}{*}{$\begin{array}{l}\text { Clast density and } \\
\text { vesicularity }\end{array}$} & \multicolumn{2}{|c|}{ Lateral variability of magma within the conduit } & $\begin{array}{l}\text { Houghton and Wilson 1989; } \\
\text { Kennedy et al. 2005; } \\
\text { Kueppers et al. 2005; } \\
\text { Mueller et al. 2011; } \\
\text { Barker et al. } 2012 \\
\end{array}$ \\
\hline & \multirow{2}{*}{ Dense juvenile } & Presence of outgassed magma & $\begin{array}{l}\text { Sable et al. 2006; } \\
\text { Lautze and Houghton 2005; 2007; } \\
\text { 2008; } \\
\text { Polacci et al. 2008; 2009a; b; 2012; } \\
\text { Gurioli et al. 2005; 2014; } \\
\text { Shea et al. 2011; 2012; 2014; } \\
\text { Cimarelli et al. 2010 }\end{array}$ \\
\hline & & Presence of a plug & $\begin{array}{l}\text { Hoblitt and Harmon 1993; } \\
\text { D’Oriano et al. 2005; } \\
\text { Sable et al. 2009; } \\
\text { Adams et al. 2006a; 2006b; } \\
\text { Giachetti et al. 2010; } \\
\text { Barker et al. 2012; } \\
\text { Lavallée et al. 2012 }\end{array}$ \\
\hline $\begin{array}{l}\text { Clast permeability and } \\
\text { connectivity }\end{array}$ & \multicolumn{2}{|c|}{ Degassing history experienced by the magma } & $\begin{array}{l}\text { Eichelberger et al. 1986; } \\
\text { Klug and Cashman 1996; } \\
\text { Saar and Manga 1999; } \\
\text { Jouniaux et al. 2000; } \\
\text { Blower 2001a, b; } \\
\text { Klug et al. 2002; } \\
\text { Melnik and Sparks 2002; } \\
\text { Rust and Cashman 2004; 2011; } \\
\text { Mueller et al. 2005; 2008; } \\
\text { Wright et al. 2006; 2007; 2009; } \\
\text { Plats et al. 2007; } \\
\text { Bernard et al. 2007; } \\
\text { Takeuchi et al. 2008; } \\
\text { Nakamura et al. 2008; } \\
\text { Bouvet de Maisonneuve et al. 2009; } \\
\text { Yokoyama and Takeuchi 2009; } \\
\text { Bai et al. 2010; 2011; } \\
\text { Degruyter et al. 2010a; 2010b; } 2012\end{array}$ \\
\hline
\end{tabular}




\begin{tabular}{|c|c|c|}
\hline & & $\begin{array}{l}\text { Vinkler et al. 2012; } \\
\text { Polacci et al. 2012; 2014; } \\
\text { Nguyen et al. 2014; } \\
\text { Pioli et al. 2008; } \\
\text { Formenti and Druitt 2003; } \\
\text { Giachetti et al. 2010; } \\
\text { Shea et al. 2011; 2012 }\end{array}$ \\
\hline Clast conductivity & Input parameters for numerical percolation simulations & $\begin{array}{l}\text { Le Pennec et al; 2001; } \\
\text { Bernard et al. 2007; } \\
\text { Wright et al. 2009; } \\
\text { Wright et Cashman } 2014\end{array}$ \\
\hline \multirow{3}{*}{ Vesicle shape and size } & Bubble coalescence, ripening or collapse signatures & $\begin{array}{l}\text { Klug and Cashman 1996; } \\
\text { Mangan and Cashmann 1996; } \\
\text { Gurioli et al. 2005; } \\
\text { Shin et al. 2005; } \\
\text { Sable et al. 2006; } \\
\text { Polacci et al. 2008; } \\
\text { Castro et al. 2012 }\end{array}$ \\
\hline & $\begin{array}{l}\text { Shear conditions in the conduit } \\
\text { Convection in the conduit }\end{array}$ & $\begin{array}{l}\text { Marti et al. 1999; } \\
\text { Polacci et al. 2001; 2003; } \\
\text { Rust et al. 2003; } \\
\text { Okumura et al. 2006; 2008; } \\
\text { Bouvet de Maisonneuve et al. 2009; } \\
\text { Wright and Weinberg 2009; } \\
\text { Laumonier et al. 2011; } \\
\text { Shea et al. 2011; 2012 } \\
\text { Carey et al. 2013 }\end{array}$ \\
\hline & Eruptive style & Moitra et al. 2013 \\
\hline \multirow{3}{*}{$\begin{array}{l}\text { Vesicle size distributions } \\
\text { (VSDs) }\end{array}$} & Vesicle nucleation processes and growth in magmas & $\begin{array}{l}\text { Klug and Cashman 1994; } \\
\text { Shea et al 2010a; } \\
\text { LaRue et al. 2013, and references } \\
\text { therein }\end{array}$ \\
\hline & Total number of nucleation, coalescence or ripening events & $\begin{array}{l}\text { Gaonac'h et al. 1996a; b } \\
\text { Klug and Cashman 1996; } \\
\text { Herd and Pinkerton 1997; } \\
\text { Blower et al. 2001; 2002; } \\
\text { Gaonac'h et al. 2003; 2005; } \\
\text { Lovejoy et al. 2004, } \\
\text { Yamada et al. 2008; } \\
\text { Bai et al. 2008; } \\
\text { Costantini et al. } 2010\end{array}$ \\
\hline & $\begin{array}{l}\text { Post-fragmentation evolution as indicator of : } \\
\text { i) fountaining mechanisms } \\
\text { ii) transportation and dispersal of the pyroclasts in submarine } \\
\text { environment }\end{array}$ & $\begin{array}{l}\text { Polacci et al; 2006a; } \\
\text { Gurioli et al; 2008; } \\
\text { Stovall et al. 2011; 2012; } \\
\text { Schipper at al. 2010a, b, c; 2011; } \\
\text { 2012; } \\
\text { Rotella et al. 2013; } 2014\end{array}$ \\
\hline \multirow{4}{*}{$\begin{array}{l}\text { Vesicle Number density } \\
(\mathrm{Nv})\end{array}$} & $\begin{array}{l}\text { Link with magma mass eruption rate (MER), } \\
\text { link with column height }\end{array}$ & $\begin{array}{l}\text { Polacci et al. 2006b; } \\
\text { Toramaru 2006; } \\
\text { Gurioli et al. 2008; } \\
\text { Carey et al. 2009; } \\
\text { Houghton et al. 2010; } \\
\text { Rust and Cashman 2011; } \\
\text { Alfano et al. } 2012\end{array}$ \\
\hline & Magma decompression rate & $\begin{array}{l}\text { Mangan and Sisson 2000; } \\
\text { Suzuki and Nakada 2001; 2002; } \\
\text { Toramaru 2006; } \\
\text { Cluzel et al. 2008; } \\
\text { Shea et al. 2010b; 2011; 2012; } \\
\text { Wright et al. } 2012\end{array}$ \\
\hline & Phreatomagmatic fragmentation & $\begin{array}{l}\text { Tsukui and Suzuki 1995; } \\
\text { Suzuki, Nakada 2001, 2002; } \\
\text { Shimano and Nakada 2006; } \\
\text { Mattsson 2010; } \\
\text { Murtagh et al. 2011; } \\
\text { Murtagh and White } 2013\end{array}$ \\
\hline & $\begin{array}{l}\text { Link vesicularity with external trigger mechanisms (crystallinity, } \\
\text { pressure changes) }\end{array}$ & $\begin{array}{l}\text { Belien et al. 2010; } \\
\text { Carey et al. 2012; } \\
\text { Gurioli et al. } 2014\end{array}$ \\
\hline
\end{tabular}




\begin{tabular}{|c|c|c|}
\hline \multirow{6}{*}{$\begin{array}{l}\text { Crystal size distribution } \\
\text { (CSD) }\end{array}$} & $\begin{array}{l}\text { Crystal size (mean, modal, and maximum crystal size), crystallization } \\
\text { kinetics (nucleation and growth rates), } \\
\text { annealing, crystal accumulation, and fractionation }\end{array}$ & $\begin{array}{l}\text { Cashman and Marsh, 1988; } \\
\text { Marsh 1988; 1998; 2007; } \\
\text { Cashman 1993; } \\
\text { Armienti et al. 1994; } \\
\text { Higgins 2000; 2002a;b; 2006; 2011; } \\
\text { Wilhelm and Worner, 1996; } \\
\text { Bindeman 2003; } \\
\text { Gualda 2006; } \\
\text { Gualda and Rivers 2006; } \\
\text { Mock et al. 2003; } \\
\text { Simakin and Bindeman, 2008; } \\
\text { Spillar and Dolejs 2013 }\end{array}$ \\
\hline & Magma ascent rate & $\begin{array}{l}\text { Cashman 1992; } \\
\text { Rutherford and Hill 1993; } \\
\text { Rutherford and Devine 2003; } \\
\text { Noguchi et al. 2008; } \\
\text { D'Oriano et al. 2011 }\end{array}$ \\
\hline & Pre-eruptive decompression paths & $\begin{array}{l}\text { Hammer et al. } 1999 \\
\text { Szramek et al. } 2006 \\
\text { Clarke et al. } 2007 \\
\text { Innocenti et al. } 2013\end{array}$ \\
\hline & Magma storage conditions prior to eruption and residence times & $\begin{array}{l}\text { Mangan 1990; } \\
\text { O’Driscoll et al. 2007; } \\
\text { Cigolini et al. } 2008 \\
\text { Simakin and Bindeman 2008; } \\
\text { Magee et al. 2010; } \\
\text { Shea et al. } 2009\end{array}$ \\
\hline & Water exsolution rate meter & Toramaru et al. 2008 \\
\hline & Magma mixing & $\begin{array}{l}\text { Morgan et al. 2007; } \\
\text { Jerram et al. } 2003\end{array}$ \\
\hline $\begin{array}{l}\text { Crystal+Vesicle size and } \\
\text { percentage }\end{array}$ & $\begin{array}{l}\text { Three phases magma rheology, } \\
\text { fluid mechanical behavior of magma }\end{array}$ & $\begin{array}{l}\text { Gurioli et al. 2014; } \\
\text { Noguchi et al. } 2006\end{array}$ \\
\hline
\end{tabular}

